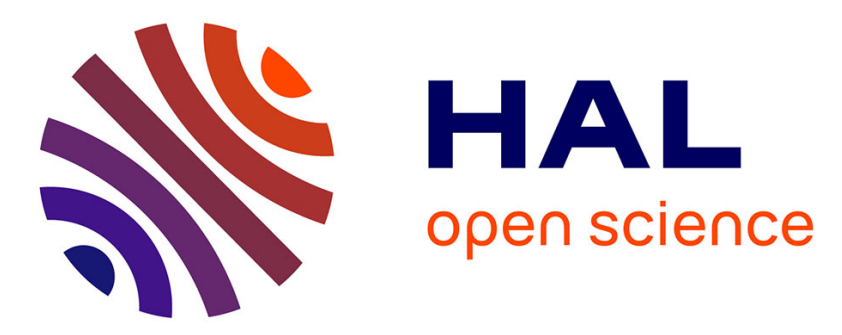

\title{
Melt inclusions track melt evolution and degassing of Etnean magmas in the last $15 \mathrm{ka}$
}

Emanuela Gennaro, Giada Iacono-Marziano, Antonio Paonita, Silvio Rotolo, Caroline Martel, Andrea Rizzo, Michel Pichavant, Marcello Liotta

\section{To cite this version:}

Emanuela Gennaro, Giada Iacono-Marziano, Antonio Paonita, Silvio Rotolo, Caroline Martel, et al.. Melt inclusions track melt evolution and degassing of Etnean magmas in the last 15 ka. Lithos, 2019, 324-325, pp.716-732. 10.1016/j.lithos.2018.11.023 . insu-01936628

\section{HAL Id: insu-01936628 \\ https://hal-insu.archives-ouvertes.fr/insu-01936628}

Submitted on 27 Nov 2018

HAL is a multi-disciplinary open access archive for the deposit and dissemination of scientific research documents, whether they are published or not. The documents may come from teaching and research institutions in France or abroad, or from public or private research centers.
L'archive ouverte pluridisciplinaire HAL, est destinée au dépôt et à la diffusion de documents scientifiques de niveau recherche, publiés ou non, émanant des établissements d'enseignement et de recherche français ou étrangers, des laboratoires publics ou privés. 


\section{Accepted Manuscript}

Melt inclusions track melt evolution and degassing of Etnean magmas in the last $15 \mathrm{ka}$

Emanuela Gennaro, Giada Iacono-Marziano, Antonio Paonita, Silvio G. Rotolo, Caroline Martel, Andrea L. Rizzo, Michel Pichavant, Marcello Liotta

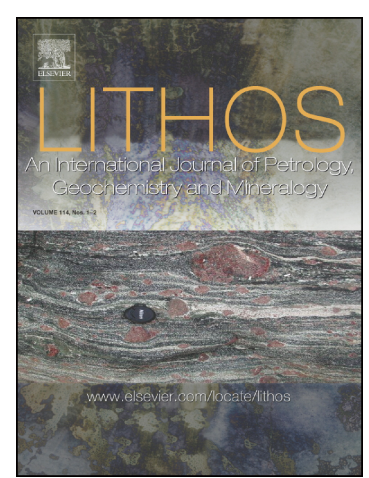

PII: S0024-4937(18)30444-4

DOI: https://doi.org/10.1016/j.lithos.2018.11.023

Reference: LITHOS 4877

To appear in:

LITHOS

Received date: 20 April 2018

Accepted date: 17 November 2018

Please cite this article as: Emanuela Gennaro, Giada Iacono-Marziano, Antonio Paonita, Silvio G. Rotolo, Caroline Martel, Andrea L. Rizzo, Michel Pichavant, Marcello Liotta, Melt inclusions track melt evolution and degassing of Etnean magmas in the last $15 \mathrm{ka}$. Lithos (2018), https://doi.org/10.1016/j.lithos.2018.11.023

This is a PDF file of an unedited manuscript that has been accepted for publication. As a service to our customers we are providing this early version of the manuscript. The manuscript will undergo copyediting, typesetting, and review of the resulting proof before it is published in its final form. Please note that during the production process errors may be discovered which could affect the content, and all legal disclaimers that apply to the journal pertain. 


\title{
Melt inclusions track melt evolution and degassing of Etnean magmas in the last $15 \mathrm{ka}$
}

Emanuela Gennaro ${ }^{1,2 *}$, Giada Iacono-Marziano ${ }^{2}$, Antonio Paonita $^{3}$, Silvio G. Rotolo ${ }^{1,3}$, Caroline Martel $^{2}$, Andrea L. Rizzo ${ }^{3}$, Michel Pichavant ${ }^{2}$, Marcello Liotta ${ }^{3}$

1 Dipartimento Scienze della Terra e del Mare (DiSTeM), Università degli Studi di Palermo, Via Archirafi 22, 90123 Palermo, Italy

${ }^{2}$ Institut des Sciences de la Terre d'Orléans (ISTO) UMR 7327, Université d'Orléans -CNRS BRGM, Campus Géosciences, 1A rue de la Férollerie, 45071 ORLEANS Cedex 2 (France)

${ }^{3}$ Istituto Nazionale di Geofisica e Vulcanologia, Sezione di Palermo, Via Ugo La Malfa 153, 90146 Palermo, Italy

(*corresponding author: emanuelagennaro@live.it)

\begin{abstract}
We present major elements compositions and volatiles contents of olivine-hosted melt inclusions from Etna volcano (Italy), which extend the existing database with the aim of interpreting the chemical variability of Etnean magmas over the last $15 \mathrm{ka}$. Olivine phenocrysts were selected from
\end{abstract}


the most primitive Fall Stratified (FS) eruptive products of picritic composition (Mg\#=67-70, Fo8991), the Mt. Spagnolo eccentric lavas (Mg\#=52-64, Fo ${ }_{82-88}$ ) and among the more recent 2002-2013 eruptive products $\left(\mathrm{Mg} \#=33-53, \mathrm{Fo}_{68-83}\right)$. Crystal fractionation and degassing processes were modeled at temperatures of $1050-1300{ }^{\circ} \mathrm{C}$, pressures $<500 \mathrm{MPa}$, and oxygen fugacity between 1 and $2 \log$ units above the nickel-nickel oxide buffer, in order to interpret melt inclusions data.

Melt inclusions show a great variability in major elements chemistry (e.g., 44-57 wt.\% $\mathrm{SiO}_{2}$, 3-16 wt.\% $\mathrm{CaO}, 4-13$ wt.\% $\mathrm{FeO}, 2-12$ wt.\% $\mathrm{MgO}$, 1-6 wt.\% $\mathrm{K}_{2} \mathrm{O}$ ), designating a continuous differentiation trend from FS toward 2013 entrapped melts, which is mostly reproduced by the fractional crystallization of olivine + spinel + clinopyroxene \pm plagioclase, in order of appearance. Volatile contents in the glass inclusions are also extremely variable, with maxima up to 6 wt.\% $\mathrm{H}_{2} \mathrm{O}$ and 0.6 wt. $\% \mathrm{CO}_{2}$ in FS melt inclusions, and up to 0.43 wt.\% $\mathrm{S}$ in Mt. Spagnolo inclusions. $\mathrm{H}_{2} \mathrm{O}$ and $\mathrm{CO}_{2}$ contents in the melt inclusions suggest minimum entrapment depths of $4-19 \mathrm{~km}$ (below crater level) for FS inclusions and $<10 \mathrm{~km}$ for the 2002-2013 trachybasalts.

Petrological arguments coupled to the modeling of fractional crystallization and degassing processes concur to suggest that magmas from Mt. Spagnolo and the recent eruptions may be produced by differentiation from the most primitive volatile-rich FS magma along variable P-T paths, occasionally accompanied by secondary processes as crustal assimilation, mixing, and $\mathrm{CO}_{2}$ flushing. We do not exclude the occurrence of source processes at Etna, e.g., variable degrees of mantle melting and/or variable degrees of mantle contamination, already proposed by previous authors. Our data, nevertheless, suggest that the first-order features of the Etnean magmas erupted in the last $15 \mathrm{ka}$ can be modeled by differentiation through fractional crystallization and degassing.

\section{Keywords:}

Etna, silicate melt inclusions, volatile contents, melt differentiation, degassing 


\section{Introduction}

Mount Etna is a persistently active strato-volcano, located in the east sector of Sicily (Italy), seated on the boundary of the colliding African and European plates and close to the Aeolian volcanic arc (e.g., Branca et al., 2011; Clocchiatti et al., 1998). Etna's activity started as a submarine volcano $\sim 500 \mathrm{ka} \mathrm{BP}$ and currently consists of lava fountains and paroxysmal activity at the summit craters, associated with lava flows, effusive to explosive activity from eruptive fissures opened on the upper flanks of the volcano, and huge emissions of volatiles in the atmosphere (e.g. Aiuppa et al., 2008; Allard et al., 2006).

The origin of magmatic activity in the Etna area and its evolution are still matter of debate. Among the different hypotheses we can mention: (i) a hot spot origin (Clocchiatti et al., 1998; Tanguy et al., 1997), (ii) an asymmetric rifting process (Continisio et al., 1997), (iii) a lithospheric 'window' created by the differential rollback of the subduction sectors between the Ionian oceanic domain and the Sicilian continental crust resulting in mantle decompression, partial melting, and the ascent of asthenospheric material from under the neighboring African plate (Doglioni et al., 2001; Gvirtzman and Nur, 1999). During the oldest volcanic stages ( 220 ka ago), Etnean magma recorded the important chemical variation from tholeiitic toward $\mathrm{Na}$-alkaline affinity (Corsaro and Pompilio, 2004a; Tanguy, 1978).

In the last decades, several researchers have observed that the composition of the recent eruptive products (since 1971) has become more enriched in alkalis (K, Rb, Cs) and radiogenic $\mathrm{Sr}$ and $\mathrm{B}$ elements (e.g., Allard et al, 2006; Armienti et al., 2004; Ferlito and Lanzafame, 2010; Métrich et al., 2004). This enrichment was inferred to result from the interaction between an OIB-type (or HIMU-type) mantle source with an enriched component (EM1), i.e., a slab-derived mantle component (Kamenetsky and Clocchiatti, 1996; Schiano et al., 2001), also possibly including $\delta^{11} \mathrm{~B}-$ enriched fluids (Armienti et al., 2004; Tonarini et al., 2001) released from the nearby Ionian slab subducting below the Aeolian Archipelago. Others studies attributed this enrichment to (i) magma 
contamination during its migration to the surface by assimilation of basement rocks (carbonates, shales, quartzarenites) (e.g., Clocchiatti et al., 1988; Joron and Treuil, 1984; Michaud et al. 1995; Tonarini et al., 1995), (ii) mixing of mantle-derived-magmas with a K- and Si-enriched melt (Schiano and Clocchiatti, 1994), (iii) magma contamination with the uprising supercritical fluids carrying alkalis and chlorine, this process being recurrent within Etnean activity (Ferlito and Lanzafame, 2010; Ferlito et al., 2014). Recently, Correale et al. (2014) suggested that the primitive magmas are produced by different melting degree of a peridotite veined by clinopyroxenite, similar to mantle samples exposed in the close Hyblean plateau. Notwithstanding the numerous studies, several aspects of Etna activity are still not fully understood, including the causes of chemical variations between Etnean magmas and the volatiles contents of the most primitive magmas.

In this paper, we focus on the magmas erupted in the last $15 \mathrm{ka}$ (Mongibello volcano, Branca et al., 2011), providing further geochemical and petrological information on magma chemical composition and volatile contents from deep storage to ascent conditions through the study of olivine-hosted melt inclusions (hereafter MIs). Melt inclusions entrapped in olivine crystals have the potential to give information on the chemical composition and volatile contents of magma in its deeper conditions and during magmatic ascent, this information being normally lost by using bulk rock and matrix glass data.

Studied MIs were selected from tephra and lava of six eruptions from central activity (2006, 2008/2009, 2013) and from eccentric or deep-dike fed (DDF, Corsaro et al., 2009) eruptions (Mt. Spagnolo, FS, 2002/2003). All products were characterized for their chemical compositions (major elements) and volatiles contents $\left(\mathrm{H}_{2} \mathrm{O}, \mathrm{CO}_{2}, \mathrm{~S}\right.$ and $\left.\mathrm{Cl}\right)$. Some of these products are investigated here for the first time (i.e., 2008/2009, 2013 and Mt. Spagnolo for its volatile content). In order to obtain a more reliable dataset and to ensure the internal consistency of this new dataset, all the analyses were performed in the same laboratories with the same analytical conditions and reference materials. 
In this work, we attempt to reconcile the different petrological and geochemical features of these mafic magmas, revealed by our new MI data and those of the literature. Differently from previous studies, attributing the origin of magmatic heterogeneity principally to variations of the magmatic source, we ascribe the first-order chemical variability of the Mongibello magmas mainly to crystal fractionation and degassing processes within the plumbing system. Heterogeneity of the mantle source would thus assume a minor role, at least as concerns major elements. We also discuss the possible role of other magmatic processes (magma mixing, assimilation of sedimentary host rocks, deep volatile flushing) that may contribute to the variability in the chemical composition, redox conditions and high volatile content of the most primitive Etnean magmas.

\section{Samples and analytical procedures}

\subsection{Target eruptions and their products}

The investigated samples consist of primitive and more evolved lavas and pyroclastic products belonging to the Mongibello period (last $15 \mathrm{ka} \mathrm{BP}$ ):

- Monte Spagnolo lavas ( 15-4 ka BP) were produced by a DDF eruption (Corsaro and Métrich, 2016; Kamenetsky and Clocchiatti, 1996). The Monte Spagnolo scoria cone is located about 6 $\mathrm{km}$ north-west of the present-day central crater (Fig. 1a). Due to its mineralogical assemblage and composition, principally olivine (Fo ${ }_{74-89}$, Table SI5) and clinopyroxene (Fs= 7-12 mol.\%), Mt. Spagnolo lava is considered as one of the most primitive magmas erupted in Etnean history (e.g., Armienti et al., 1988; Correale et al., 2014). Mt. Spagnolo melt inclusions in olivine crystals have been already characterized for their chemical compositions (Kamenetsky and Clocchiatti, 1996).

- FS tephra ( 4 ka BP) were ejected by a DDF highly-explosive (sub-Plinian) eruption (Coltelli et al., 2005), and its spread is mostly located in the east and north flanks of the volcano (Fig. 1a), reaching a maximum thickness of $110 \mathrm{~cm} 7 \mathrm{~km}$ away from the summit craters. This 
eruption was fed by a volatile-rich picro-basalt magma $(\mathrm{MgO} \sim 13-17.6$ wt.\%, $\mathrm{Ni} \sim 250 \mathrm{ppm}, \mathrm{Cr}$ 900 ppm, from Correale et al., 2014; Corsaro and Métrich, 2016; Kamenetsky et al., 2007; Pompilio et al., 1995), representing the most primitive magma ever erupted at Etna (Pompilio et al., 1995). The high volatile content, the unusual enrichment of large-ion lithophile element (LILE), and the relatively high ${ }^{87} \mathrm{Sr}$ and low ${ }^{143} \mathrm{Nd}$ isotopic composition suggest the possible contribution of crustal fluids in the mantle source zone (e.g., Correale et al., 2014). Melt inclusions from this eruption have been already characterized for their chemical composition and volatile content (Corsaro and Métrich, 2016; Kamenetsky et al., 2007).

- 2002/2003 tephra were produced by a lateral strombolian eruption along the South rift (Fig. 1a). During this eruptive period, the Northeast rift and summit craters were also active (e.g., Andronico et al., 2005; Spilliaert et al., 2006a). A particular feature of this eruption is the emission of two different magmas: (i) a plagioclase-rich, partially degassed trachybasaltic lava, from the NE rift, and (ii) undegassed plagioclase-free basaltic lava flows and tephra from the Srift (Spilliaert et al., 2006a). Melt inclusions from this eruption have been already characterized for chemical composition and volatile content (Collins et al., 2009; Schiavi et al., 2015; Spilliaert et al., 2006). In this study, we focus on the products from the S-rift activity.

- 2006 tephra were produced by a sub-terminal eruption that took place from three new vents opened along the flank of the South East Crater (SEC), producing several tephra cones and lava flow (Fig. 1b), and from the summit crater. Melt and fluid inclusions have been already characterized for volatile and trace elements abundance by Collins et al. (2009) and Schiavi et al. (2015). The emitted magma was interpreted as residual of the 2001-2003 eruptive period, and the melt inclusions were inferred to track an episode of $\mathrm{CO}_{2}$ fluxing from the deep degassing of a primitive magma (Collins et al., 2009).

- 2008/2009 eruption started with the opening of eruptive fissures propagating SE from the summit craters and produced lava flows that expanded in the Valle del Bove (Bonaccorso et al., 
2011, Fig. 1b). Some intense explosions also occurred in the North East Crater (NEC), producing the tephra (bombs) investigated in this study.

- 2013 eruption (Fig. 1b) consisted of 19 paroxysms occurred at the New South East Crater (NSEC) associated to lava flows from fractures opened mostly along the NSEC cone. The sampled lava flow was associated to the paroxysm occurred in April.

\subsection{Methods}

Major elements analyses of the finely powdered $(<10 \mu \mathrm{m})$ whole rocks (wr) were performed by Xray fluorescence spectroscopy at the ActLab Laboratories in Canada, following the internal procedures (Norrish and Hutton, 1969). Analytical uncertainty $(1 \sigma)$ for major elements is $<1 \%$ for $\mathrm{SiO}_{2}$ and $\mathrm{Al}_{2} \mathrm{O}_{3},<2 \%$ for $\mathrm{Fe}_{2} \mathrm{O}_{3}, \mathrm{MgO}, \mathrm{CaO}, \mathrm{Na}_{2} \mathrm{O}$ and $\mathrm{K}_{2} \mathrm{O},<5 \%$ for $\mathrm{MnO}, \mathrm{TiO}_{2}$ and $\mathrm{Cr}_{2} \mathrm{O}_{3}$ and $5-10 \%$ for $\mathrm{P}_{2} \mathrm{O}_{5}$.

$\mathrm{Cl}$ and $\mathrm{S}$ in the whole rocks were determined by INAA (Instrumental Neutron Activation Analysis) and IR (infrared) methods, respectively. In particular, S is measured using the high frequency induction heated furnace, coupled to infrared detectors (Leco CS 244 analyzer for low-level sulfur). Induced electrical currents heat the sample, at which an accelerator (useful to ease the ignition) is added. The pure oxygen environment and the produced heat cause the sample combustion, through which sulfur-bearing elements release sulfur that is converted to $\mathrm{SO}_{2}$ and measured in the IR cell.

Rock samples and melt inclusions were observed by two scanning electron microscopes (SEM): a Tescan MIRA 3 XMU (BRGM, Orléans) and a Zeiss Merlin Compact (ISTO, Orléans). Images and semi-quantitative spectra were acquired using $25 \mathrm{keV}$ (Tescan MIRA 3 XMU) and 15 keV (Zeiss Merlin Compact) electron energy.

A Cameca SX FIVE electron microprobe (ISTO, Orléans) was used to analyze major elements in glass inclusions and embayments, matrix glasses, olivine phenocrysts, and Fe-Ti oxides as well as the $\mathrm{S}$ and $\mathrm{Cl}$ concentrations in melt inclusions. Acquisitions were carried out using an acceleration 
voltage of $15 \mathrm{keV}$, a $6 \mathrm{nA}$ beam current and a peak counting time of $10 \mathrm{~s}$ for all the elements, excepting for $\mathrm{S}(60 \mathrm{~s})$. A focused beam was used for olivine and Fe-Ti oxide crystals, whereas a defocused beam of 2-6 $\mu \mathrm{m}$ size was used for melt inclusions and embayments to reduce $\mathrm{Na}$ migration. Natural minerals and oxides were used as standards ( $\mathrm{Na}$ and $\mathrm{Si}$ : albite, $\mathrm{K}$ : anorthoclase, Ca: anhydrite, P: apatite, $\mathrm{Cl}$ : vanadinite, $\mathrm{Mg}: \mathrm{MgO}$, $\mathrm{Al}: \mathrm{Al}_{2} \mathrm{O}_{3}, \mathrm{Fe}: \mathrm{Fe}_{2} \mathrm{O}_{3}$, Ti and $\mathrm{Mn}: \mathrm{MnTiO}_{3}$ ). S was calibrated against barite $\left(\mathrm{BaSO}_{4}\right)$. Analytical uncertainty $(1 \sigma)$ is $<1 \%$ for $\mathrm{SiO}_{2}, \mathrm{Al}_{2} \mathrm{O}_{3}$ and $\mathrm{CaO}$, $<3 \%$ for $\mathrm{FeO}, \mathrm{MgO}$ and $\mathrm{TiO}_{2},<5 \%$ for $\mathrm{MnO}, \mathrm{Na}_{2} \mathrm{O}$ and $\mathrm{K}_{2} \mathrm{O} ;<500$ ppm for $\mathrm{S}$ and $\mathrm{Cl}$ and detection limits are 120-450 ppm and 240-900 ppm, respectively for S and Cl.

$\mathrm{H}_{2} \mathrm{O}$ and $\mathrm{CO}_{2}$ contents in the glass phase were determined by transmission Fourier transform infrared spectroscopy (FTIR) using a Nicolet 760 Magna spectrometer equipped with an IR microscope and an MCT detector (ISTO, Orléans). Doubly-polished glass inclusions were accurately prepared to obtain 18-72 $\mu \mathrm{m}$ thick chips. The thickness of the chip was estimated using a petrographic microscope, through repeated measurements. For each melt inclusion, at least two spectra were acquired to check the homogeneity of dissolved $\mathrm{H}_{2} \mathrm{O}$ and $\mathrm{CO}_{2}$ contents. Absorption spectra were acquired in the range $1000-6000 \mathrm{~cm}^{-1}$ with $128 / 560$ scans and a resolution of $4 \mathrm{~cm}^{-1}$, using a Globar internal IR source and a $\mathrm{KBr}$ beam-splitter. The concentrations (C) of $\mathrm{H}_{2} \mathrm{O}$ and $\mathrm{CO}_{2}$ dissolved in MIs were calculated from the absorbancies (A) of the $3530 \mathrm{~cm}^{-1}$ (total water vibration) and the $1430 \mathrm{~cm}^{-1}\left(\mathrm{CO}_{3}{ }^{2-}\right.$ bending $)$ bands, respectively, using the modified Beer-Lambert law (Stolper, 1982):

$$
C=\left(\left(M W^{*} A\right) /\left(d^{*} l^{*} \varepsilon\right) * 100\right)
$$

where $\boldsymbol{M W}$ is the molecular weight (in g/mol), $\boldsymbol{d}$ the melt density (in g/l), $\boldsymbol{\varepsilon}$ the molar absorption coefficient (in $1 \cdot \mathrm{mol}^{-1} \cdot \mathrm{cm}^{-1}$ ), $\boldsymbol{l}$ the optic path (i.e. the thickness of the sample, in $\mathrm{cm}$ ). A molar extinction coefficient $(\varepsilon)$ of $631 \cdot \mathrm{mol}^{-1} \cdot \mathrm{cm}^{-1}$ was used for the $3530 \mathrm{~cm}^{-1}$ band (Dixon et al., 1988), whereas the coefficient for the $1430 \mathrm{~cm}^{-1}$ band was calculated for each MI $\left(300-4161 \cdot \mathrm{mol}^{-1} \cdot \mathrm{cm}^{-1}\right)$ on the basis of the $\mathrm{Na} /(\mathrm{Na}+\mathrm{Ca})$ molar ratio of the melt, using the Dixon and Pan (1995) method. The 
absorbancies of the carbonate doublet were estimated after subtraction of a spectrum of a $\mathrm{CO}_{2}$-free synthetic glass, with similar composition and $\mathrm{H}_{2} \mathrm{O}$ content (Lesne et al., 2011). The melt density for each inclusion was variable in the range $\left(\mathrm{d}=2.68-2.76 \mathrm{~g} \cdot \mathrm{cm}^{-3}\right)$ and was calculated by using a

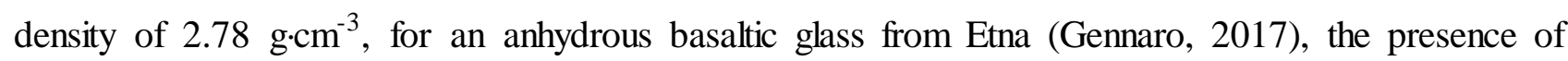
dissolved water being accounted for with the method proposed by Richet et al. (2000).

The sample thickness probably represents the most important source of uncertainty for these analyses, with repeated measurements giving standard variations between 1 and $8 \%$, which imply uncertainties up to \pm 2 wt.\% $\mathrm{H}_{2} \mathrm{O}$ and $900 \mathrm{ppm} \mathrm{CO}_{2}$ (for the thinnest samples). Another source of error is the molar absorption coefficient. Tests carried out using the coefficients for the $3530 \mathrm{~cm}-1$ band from previous studies (e.g., Stolper, 1982; Fine and Stolper, 1986; Dixon et al., 1988; Ihinger et al., 1994; Metrich et al., 2001; Shishkina et al., 2010) suggest a further uncertainty of \pm 0.3 wt.\% $\mathrm{H}_{2} \mathrm{O}$.

$\mathrm{H}_{2} \mathrm{O}, \mathrm{CO}_{2}$, and $\mathrm{S}$ contents of melt inclusions were also determined through secondary ion mass spectrometry (SIMS) using the Cameca IMS 1270 and the IMS 1280 HR2 ion microprobes at CRPG, (Nancy, France). Olivine hosted melt inclusions and standard reference glasses were pressed into indium within an aluminum disk, then gold coated and outgassed in the SIMS chamber until a pressure of $10^{-8}-10^{-9}$ Torr was reached. The acquisition, preceded by a $30 \mathrm{~s}$ of pre-sputtering period (needed to erase impurities from the sample surface), was performed using a $\mathrm{Cs}^{+}$primary beam of 5 $\mathrm{nA}$, with an impact energy of $20 \mathrm{kV}$ in 12-15 cycles. The secondary beam consisted of both ionized atoms, commonly used as analytes for volatile determinations (e.g., ${ }^{12} \mathrm{C}^{-},{ }^{32} \mathrm{~S}^{-}$), and ionized hydride molecules that create numerous interferences. A mass resolving power (MRP) of 7000 was used for separating these interfering species. In order to check the accuracy on the determined concentrations, glasses with compositions similar to the Etna samples were used as secondary standards. For $\mathrm{H}_{2} \mathrm{O}$ and $\mathrm{CO}_{2}$ : basalts N72 from Kamchatka and the KL2-G basalt from Kilauea [04.2 wt.\% and 0-3172 ppm respectively (Jochum et al., 2006; Shishkina et al., 2010)] were used and, for S the KL2-G, VG-2 and A99 standard glasses (Jarosewich et al., 1979; Witter et al., 2005, 0- 
1406 ppm). The signals for all volatiles $\left({ }^{12} \mathrm{C}^{-},{ }^{16} \mathrm{O}^{1} \mathrm{H}^{-},{ }^{32} \mathrm{~S}^{-}\right)$were gathered in mono-collection mode during the same analysis (acquisition time $12 \mathrm{mn}$ ). Concentrations of all volatiles (except $\mathrm{H}_{2} \mathrm{O}$ ) were calculated by comparing the ${ }^{12} \mathrm{C}^{-} /{ }^{28} \mathrm{Si}^{-}$vs. $\mathrm{SiO}_{2}$ (for $\mathrm{CO}_{2}$ ) and the ${ }^{32} \mathrm{~S}^{-28} \mathrm{Si}^{-}$vs. $\mathrm{SiO}_{2}$ (for $\mathrm{S}$ ) in the sample and in the reference glass. $\mathrm{H}_{2} \mathrm{O}$ was calculated by comparing the $\mathrm{OH}^{-} / \mathrm{H}^{-}$vs. $\mathrm{H}_{2} \mathrm{O}$ in the reference materials with the $\mathrm{OH}^{-} / \mathrm{H}^{-}$of the sample. When available, SIMS data are preferred to FTIR data, due to their lower uncertainties.

\section{Results}

\subsection{Whole rocks compositions}

Major element compositions of the studied lavas and tephra are reported in Table 1 [and plotted in the Total Alkali versus Silica (TAS) diagram (Fig. SI1)]. Our results are generally consistent with those of previous studies (e.g. Correale et al., 2014; Corsaro and Métrich, 2016; Kamenetsky and Clocchiatti, 1996; Kamenetsky et al., 2007; Spilliaert et al., 2006a; Fig. SI1). All the rocks plot within the field defined by historical alkaline lavas (Correale et al, 2014, and references therein), except for FS tephra, which are poorer in alkali and richer in $\mathrm{MgO}$ than both the historical alkaline and the oldest tholeiitic lavas (Figs. SI1, 2). The rocks from 2006, 2008/2009 and 2013 eruptions present a trachybasaltic composition, whereas the lavas from Mt. Spagnolo and 2002/2003 eruptions straddle the basaltic-trachybasaltic fields of the TAS diagram (Fig. SI1). FS tephra are picro-basaltic $\left(\mathrm{MgO}=17.9\right.$ wt.\%); they have the highest $\mathrm{CaO} / \mathrm{Al}_{2} \mathrm{O}_{3}$ ratio $(=1.23)$ and $\mathrm{Mg}$ number $(\mathrm{Mg \#}=77.5)$, and the lowest alkali content $\left(\mathrm{Na}_{2} \mathrm{O}+\mathrm{K}_{2} \mathrm{O}<2\right.$ wt.\%) among the investigated rocks. Both the $\mathrm{MgO}$ content and the $\mathrm{CaO} / \mathrm{Al}_{2} \mathrm{O}_{3}$ ratio decrease from FS, Mt. Spagnolo toward the most recent trachybasaltic compositions (asterisks in Fig. 2). When considering $\mathrm{K}_{2} \mathrm{O}$ as magma differentiation index, the investigated products show a trend of decreasing $\mathrm{MgO}$ and of broadly increasing $\mathrm{Na}_{2} \mathrm{O}, \mathrm{Al}_{2} \mathrm{O}_{3}, \mathrm{FeO}_{\text {tot }}$ and $\mathrm{TiO}_{2}$ from the most primitive FS toward the most recent and 
differentiated products (not shown). None of the analyzed whole rock composition has a clear $\mathrm{Na}$ or K-alkaline affinity, being all transitional between the two series (asterisks in Fig. 3).

\subsection{Petrography, minerals chemistry, and melt inclusions observations}

\section{Monte Spagnolo}

Mt. Spagnolo lavas are poorly-phyric (porphyricity: 10-15 vol.\%). They contain phenocrysts of subhedral clinopyroxene (the most abundant mineral phase), followed (in order of abundance) by euhedral to subhedral olivine, plagioclase, with $\mathrm{Cr}$-spinel microphenocrysts. The groundmass is microcrystalline with microlites of plagioclase, clinopyroxene (sometimes skeletal), Ti-magnetite (often dendritic) and olivine (Fig. 4a). Olivine phenocrysts have variable forsterite (Fo) contents: one group is in the range $\mathrm{Fo}_{70-76}$ and the other is Fo82-89. Some phenocrysts present reverse zoning, with $\mathrm{Fo}_{75}$ cores and $\mathrm{Fo}_{85}$ rims (Fig. 4b). Only the most primitive (Fo ${ }_{82-88}$ ) phenocrysts, which contain abundant $\mathrm{Cr}$-spinel $\left(\mathrm{Cr}_{2} \mathrm{O}_{3}=36-46\right.$ wt.\%, Table SI1) inclusions, were selected for this study.

Melt inclusions within olivine phenocrysts have variable sizes in the range between 25 and $140 \mu \mathrm{m}$, with spherical to ovoidal shapes; sometimes they contain bubbles and/or small $\mathrm{Cr}$-rich oxide and few daughter minerals (Fig. 4c). Among the studied MIs, 13 have bubble with $\mathrm{V}_{\mathrm{b}} / \mathrm{V}_{\mathrm{MI}}$ between 0.01 and 0.16 , where $\mathrm{V}_{\mathrm{b}}$ is the bubble volume, and $\mathrm{V}_{\mathrm{MI}}$ the inclusion volume, both estimated assuming a perfect spherical shape for the bubble and the inclusion.

\section{FS}

Picritic scoria lapilli are highly vesiculated (voids > 50 vol.\%) and almost aphyric (phenocrysts $\leq$ 10 vol.\%). The phenocrysts are principally represented by euhedral Fo89-91 olivine (up to $\sim 5 \mathrm{~mm}$ in size, Table SI5), followed by subhedral clinopyroxene and rare Cr-spinel microphenocrysts; these latter are enclosed within olivine phenocrysts but also occur within melt inclusions $\left(\mathrm{Cr}_{2} \mathrm{O}_{3}=46-52\right.$ 
wt.\%, Table SI1, Fig. 4d). The groundmass is glassy, with sparse microlites of olivine, clinopyroxene, plagioclase and Cr-spinel.

Melt inclusions are abundant in FS primitive olivine; they have spherical and oval shapes with typical scalloped edges (Fig. 4e). They have variable sizes, between 25 and $180 \mu \mathrm{m}$, and generally present a typical spherical vapor bubble $\left(\mathrm{V}_{\mathrm{b}} / \mathrm{V}_{\mathrm{MI}}\right.$ between 0.004 and 0.20$)$.

\section{2/2003 South}

These scoria are vesiculated (voids $~ 30$ vol.\%), poorly phyric (10-15 vol.\% phenocrysts) in agreement with previous studies (Kahl et al., 2015 and references therein). Phenocryst abundances are in the order: clinopyroxene $>$ plagioclase $>$ olivine $>$ Ti-magnetite. Olivine phenocrysts are euhedral to subhedral and have variable Fo contents (between 70 and 83 mol.\%, Table SI5). They commonly host melt inclusions and Ti-magnetite microphenocryts (Usp = 21-43\%) (Table SI1, Fig. 4f). The groundmass is microcrystalline with microlites of clinopyroxene, plagioclase, and subordinate olivine and Ti-magnetite.

Melt inclusions in olivine generally have a spherical shape (Fig. 4g), but elongated inclusions (with slightly scalloped edges) were also occasionally observed. They have variable sizes (30-150 $\mu \mathrm{m})$, sometimes with spherical bubbles $\left(\mathrm{V}_{\mathrm{b}} / \mathrm{V}_{\mathrm{MI}}\right.$ between 0.002 and 0.13$)$. Several melt inclusions in 2002/2003 trachybasalts have abundant daughter minerals; for this study, only crystal-free melt inclusions were selected and analyzed.

\section{6}

These trachybasaltic scoria are vesiculated (voids $\sim 30$ vol.\%) and porphyritic (phenocrysts $\sim 25$ vol.\%). The phenocrysts consist of plagioclase (the most abundant phase) followed by clinopyroxene and olivine and microphenocrysts of Ti-magnetite, surrounded by a microcrystalline 
groundmass with plagioclase and clinopyroxene microlites, and less abundant olivine and Timagnetite.

Olivine phenocrysts (Fo69-81, Table SI5) host many melt and Ti-magnetite (Usp $=14-40 \%$, Table SI1) inclusions, and show rare embayments (Fig. 4h). Investigated melt inclusions have variable forms (spherical, oval and elongated, sometimes with slightly scalloped edges, Fig. 4h) and sizes (18-200 $\mu \mathrm{m})$. Five MIs out of 36 present small vapor bubbles $\left(\mathrm{V}_{\mathrm{b}} / \mathrm{V}_{\mathrm{MI}}=0.007-0.037\right)$ and a few contain Ti-Fe-oxides and small sulfide globules.

\section{8/2009}

Samples collected from this eruption consist of juvenile bombs, highly vesiculated (voids $\sim 45$ vol. $\%$ ) and slightly porphyritic (20 vol. $\%$ phenocrysts). Phenocrysts consist of plagioclase > clinopyroxene $>$ olivine $>$ Ti-magnetite, while the microcrystalline groundmass includes plagioclase, clinopyroxene, and less abundant olivine and Ti-magnetite microlites. The olivine phenocrysts (Fo69-81, Table SI5) host abundant melt and fluid inclusions and Ti-magnetite crystals $(\mathrm{Usp}=14-40 \%$, Table SI1).

Investigated melt inclusions have variable sizes $(18-200 \mu \mathrm{m})$ and present spherical but also irregular forms. They contain small bubbles $\left(\mathrm{V}_{\mathrm{b}} / \mathrm{V}_{\mathrm{MI}}\right.$ between 0.008 and 0.05$)$, Ti-Fe-oxides and $\mathrm{Cu}-\mathrm{Fe}$ sulfides (Fig. 4i).

\section{3}

The 2013 lava is porphyric (20-25 vol.\% phenocrysts), with phenocrysts of plagioclase > clinopyroxene > olivine $\left(\mathrm{Fo}_{72-80}\right.$, Table $\left.\mathrm{SI} 5\right)$, and microphenocrysts of Fe-Ti-oxide. The groundmass is microcrystalline with microlites of clinopyroxene, olivine, Ti-magnetite and less abundant plagioclase, apatite and $\mathrm{Cu}-\mathrm{Fe}$ sulfides (Fig. 41). 
Olivine phenocrysts from this eruption are particularly rich in melt inclusions, whose size is in the range 15-200 $\mu \mathrm{m}$. MIs have typically spherical to ovoidal shapes, but elongated inclusions are also sometimes observed. They contain bubbles $\left(\mathrm{V}_{\mathrm{b}} / \mathrm{V}_{\mathrm{MI}}\right.$ between $\left.0.005-0.178\right)$, abundant $\mathrm{Cu}-\mathrm{Fe}$-sulfide globules, generally associated with Fe- Ti-oxides (Fig. 4m).

\subsection{Major elements composition of melt inclusions, embayments and matrix glasses}

The chemical compositions of the studied Etnean melt inclusions analyzed by EMP, FTIR, and SIMS, are reported in Table SI2, together with those of some glass embayments and matrix glasses. Several post-entrapment processes are likely to have occurred in these melt inclusions. The most common is the overgrowth of olivine at the melt inclusion interface and its re-equilibration with the host olivine, causing i.e. diffusion of $\mathrm{Fe}$ and $\mathrm{Mg}$ respectively from the melt and from the crystal, (e.g., Danyushevsky et al., 2000; Danyushevsky et al., 2002; Gaetani and Watson, 2002). In this study, the extent of post-entrapment crystallization (PEC) of olivine in the melt inclusion wall (i.e., the wt $\%$ of olivine to be added to the raw melt inclusion analysis in order to restore the equilibrium $\mathrm{K}_{\mathrm{D}}{ }^{\text {ol/melt }}$ ) was calculated assuming olivine-liquid equilibrium and a $\mathrm{K}_{\mathrm{D}}{ }^{\mathrm{ol} / \mathrm{melt}}$ $\left[(\mathrm{FeO} / \mathrm{MgO})_{\mathrm{ol}} /(\mathrm{FeO} / \mathrm{MgO})_{\text {melt }}\right]$ of $0.30 \pm 0.03$, following the methods of Métrich and Clocchiatti (1996).

Major element compositions of MIs corrected for PEC of olivine rim at the MI walls are reported in Table SI3). The observed PEC ranges between 0 and $15.5 \%$, the highest values being for the Mt. Spagnolo and FS melt inclusions (Table SI3).

Diffusion of $\mathrm{H}^{+}$("proton diffusion") may also occur through the host olivine and can lead to $\mathrm{H}_{2} \mathrm{O}$ loss or gain in the melt inclusion (e.g., Gaetani et al., 2012; Portnyagin et al., 2008; Sobolev et al., 1991; Sobolev, 1996). This can alter the chemical composition of the entrapped melts, their volatile contents and their oxygen fugacity (e.g., Bucholz et al., 2013; Danyushevsky and Plechov, 2011; 
Frezzotti, 2001). We identified a probable $\mathrm{H}^{+}$loss in Mt. Spagnolo MIs, which most likely experienced the slowest cooling rate among the studied products.

Studied melt inclusions show a great variability in major elements compositions. Silica spans a range between 44 and 57 wt.\%, total alkali between 2.4 and 14.2 wt.\%, $\mathrm{MgO}$ between 1.5 and 11.9 wt.\% and $\mathrm{CaO}$ between 3.1 and 15.8 wt.\% (Table SI3, Figs. 2, 3, 5 and SI1). The melts entrapped in the FS products have the highest $\mathrm{MgO}$ (and $\mathrm{CaO}$ ) contents and the lowest $\mathrm{Al}_{2} \mathrm{O}_{3}$ and $\mathrm{K}_{2} \mathrm{O}$ contents (Figs. 5b-c-d), suggesting that they represent the most primitive melt in this study.

Compositions of MIs trapped in the $\mathrm{MgO}$-richest olivine $\left(\sim \mathrm{Fo}_{78-91}\right)$ are generally similar to those of the associated whole rocks (Fig. 2), with the exception of FS rock having MgO content higher than those of MIs (17.9 vs. 11.9 wt.\%). This could be due to an accumulation of olivine phenocrysts in FS magma. Differently, the compositions of MIs trapped in MgO-poorer olivines $\left(\sim \mathrm{Fo}_{68-75}\right)$ are more evolved (lower $\mathrm{FeO}$ and $\mathrm{MgO}$ contents and higher alkali contents) than their respective bulk rocks (Figs. 3, 5).

Using $\mathrm{K}_{2} \mathrm{O}$ as a melt differentiation index, clear evolution trends are visible from FS compositions toward MIs of the most recent products (2008-2013), which have the highest $\mathrm{Al}_{2} \mathrm{O}_{3}, \mathrm{~K}_{2} \mathrm{O}$ and $\mathrm{Na}_{2} \mathrm{O}$, and the lowest $\mathrm{MgO}$ and $\mathrm{CaO}$ contents (Figs. 5). $\mathrm{SiO}_{2}$ is generally enriched in MIs from the most differentiated / most recent products. $\mathrm{FeO}_{\text {tot }}, \mathrm{TiO}_{2}$ and $\mathrm{P}_{2} \mathrm{O}_{5}$ show large variations (4.3-12.5 wt.\%, 0.7-2.6 wt.\%, and 0-1.7 wt.\% respectively) and no clear trends appear with $\mathrm{K}_{2} \mathrm{O}$ (Figs. 5). As their respective whole rocks, all MIs belong to the alkaline series, except the MIs in FS, which are tholeiitic basalts (Fig. SI1). The Mt. Spagnolo MIs have a sodic affinity $\left(\mathrm{Na}_{2} \mathrm{O}-2>\mathrm{K}_{2} \mathrm{O}\right)$, while the most recent products show no clear chemical affinity (Fig. 3).

The composition of the studied MIs is consistent with previous results obtained on the same eruptions (e.g., Collins et al., 2009; Corsaro and Métrich, 2016; Kamenetsky and Clocchiatti, 1996; Kamenetsky et al., 2007; Métrich et al., 2004; Spilliaert et al., 2006a, Fig. 2). Our study reveals that the most evolved and Mg-poor melts come from the 2013 olivine-hosted MIs and confirms that the 
primitive Etnean liquids in the last $15 \mathrm{ky}$ are the FS MIs, followed by Mt. Maletto and Mt. Spagnolo magmas (Kamenetsky and Clocchiatti, 1996). The monogenetic cone of Mt. Maletto is made of sub-aphyric primitive basalts (7.75 wt.\% MgO, Armienti et al., 1988; Corsaro and Métrich, 2016) produced by a DDF-type eruption (Armienti et al., 1988), dated 7 ka BP (Condomines et al. 1995).

Three glass embayments (Table SI2 - SI3, Fig. 3) were also analyzed (two from the 2006 and one from the 2002/2003 eruptions). One embayment in the 2006 sample is distinctly more evolved than the melt inclusion hosted in the same olivine $\left(\mathrm{CaO} / \mathrm{Al}_{2} \mathrm{O}_{3}\right.$ embayment $=0.50$ vs. 0.71 in $\mathrm{MI} ; \mathrm{K}_{2} \mathrm{O}$ embayment $=3.4$ vs.1.85 wt.\% in MI). The other two embayments have compositions similar to the inclusions entrapped in the same olivine. The few matrix glasses analyzed generally show more evolved compositions than their related melt inclusions (Table SI3, Fig. 3).

\subsection{Volatile content of melt inclusions}

Volatile $\left(\mathrm{H}_{2} \mathrm{O}, \mathrm{CO}_{2}, \mathrm{~S}, \mathrm{Cl}\right)$ abundances of the $\mathrm{MI}$ were measured only in the glass phase and were not corrected for PEC. Several studies (Danyushevsky et al., 2002; Kent, 2008; Qin et al., 1992; Schiavi et al., 2015) report that the PEC recalculation procedure affects melt concentrations and ratios of the elements that are compatible in olivine (i.e., $\mathrm{Si}, \mathrm{Fe}$, and $\mathrm{Mg}$ ). They propose that the reequilibration between melt entrapped in the host crystal and the surrounding magmas via diffusion through the host crystal is more rapid for species with higher diffusivities and higher crystal-melt partition coefficients, as well for small inclusions. Although PEC correction would result in a dilution of the incompatible elements (e.g., volatile elements) measured in MIs, Moretti et al. (2018) states that PEC values up to $11 \%$ have negligible effects on major and volatile elements. In our MIs, the PEC correction would add variable quantities to the measured volatile contents (up to $370,430,580$ ppm respectively for $\mathrm{S}, \mathrm{Cl}, \mathrm{CO}_{2}$ and up 0.35 for $\mathrm{H}_{2} \mathrm{O}$ ), but they generally stay within the estimated analytical range error (Table SI3). 
In addition to PEC, loss of volatiles from the entrapped magma may occur via several other processes, such as the bubble formation and the diffusive re-equilibration between melt entrapped in the host crystal and the surrounding magmas via diffusion thought the crystal host. Yet, we did not apply any PEC correction because the volatiles lost for diffusion through the host crystal (or into the bubbles), could not be quantified.

Sulfur contents measured by EMP and SIMS are generally in a good agreement (Fig. SI3). Due to the significantly lower detection limit of SIMS analyses $(<10 \mathrm{ppm} \mathrm{S),} \mathrm{SIMS} \mathrm{values} \mathrm{were} \mathrm{preferred}$ for MIs with S contents < 300 ppm. For MIs with $\mathrm{S}>300$ ppm, EMP values were preferred, being the EMP dataset more complete (Table SI2). For $\mathrm{H}_{2} \mathrm{O}$ and $\mathrm{CO}_{2}$, only a few inclusions were analyzed with both SIMS and FTIR (3 MIs for $\mathrm{H}_{2} \mathrm{O}$ and 1 for $\mathrm{CO}_{2}$ ), preventing us to directly compare the two methods (Table SI2).

MI volatile contents do not correlate with the extent of PEC (Figs. SI2a-b). This, together with the scarcity of Fe-Ti oxides in the investigated MIs and absence of cracks / dislocations in host crystals all concur for a good preservation of the original dissolved volatiles. However, the episodic presence of vapor bubbles suggests that the measured volatile contents $\left(\mathrm{CO}_{2}\right.$ in particular since it is strongly partitioned into the bubble) must be regarded as minimum values for pre-eruptive melts (e.g., Frezzotti, 2001; Moore et al., 2015; Wallace et al., 2015; Robidoux et al. 2017). Most vapor bubbles have $\mathrm{V}_{\mathrm{b}} / \mathrm{V}_{\mathrm{MI}}$ ratios typical of shrinkage bubbles (bubble volumes are $0.2-5 \%$ of the inclusion, from Lowenstern, 1995 and references therein). Some MIs (Mt. Spagnolo, FS, 2002/2003 and 2013) have bubbles with higher inclusion volumes (> $5 \%$ ), which could indicate postentrapment mechanisms such as rapid decompression, thermal shock (resulting in phenocryst fracturing) or depressurization-vesiculation. Bubbles with the larger vapor/melt ratio are generally considered to result from the simultaneous entrapment of melt and a separate vapor or fluid phase (Lowenstern, 1995; and references therein). In our samples, bubble-bearing MIs do not have systematically lower $\mathrm{CO}_{2}$ contents than bubble-free ones. In the same way, no systematic relation is observed between the $\mathrm{H}_{2} \mathrm{O}$ and $\mathrm{CO}_{2}$ contents and $\mathrm{V}_{\mathrm{b}} / \mathrm{V}_{\mathrm{MI}}$ (Table SI2, Figs. SI2c-d), even if MIs with 
the highest $\mathrm{CO}_{2}$ contents (> 4000 ppm) have a low $\mathrm{V}_{\mathrm{b}} / \mathrm{V}_{\mathrm{MI}}(<0.06)$. Although the $\mathrm{H}_{2} \mathrm{O}$ and $\mathrm{CO}_{2}$ contents seem uncorrelated with the inclusion size (Figs. SI2e-f), we cannot exclude that diffusive processes have significantly affected the volatiles in the MIs. In order to evaluate this process, the distance between MI and olivine rim would be also considered (Schiavi et al., 2016).

Indeed, $\mathrm{H}_{2} \mathrm{O}$ loss by $\mathrm{H}^{+}$diffusion through the host olivine probably occurred in particular in Mt. Spagnolo and 2013 MIs, which come from slowly cooled lava flows (e.g., Sobolev, 1996; Frezzotti, 2001; Gaetani et al., 2012; Lloyd et al., 2013). The small oxide crystals (Fe-Ti oxides and in some case Cr-spinel) that occur both in MIs and host crystals (Figs. 4c, 4d, 4i) are interpreted to preexist to melt entrapment (Kent, 2008; Table SI1), and not to have crystallized as a result of posttrapping water loss and/or hydrogen migration (Sobolev et al., 1994; Bucholz et al., 2013).

The $\mathrm{H}_{2} \mathrm{O}$ content of the investigated MIs is extremely variable, between 0.01 and 5.99 wt. $\%$, the highest values exceeding the range previously determined for Etnean melts (Fig. 6). The most $\mathrm{H}_{2} \mathrm{O}$ rich melt inclusions are from the FS eruption, and our results (up to 6 wt.\%) are higher than previous analyses from Kamenetsky et al. (2007; 2.6-3.8 wt\%). The 2002/2003 and 2006 MIs present variable $\mathrm{H}_{2} \mathrm{O}$ contents (between 0.1 and 3.3 wt.\%), similar to previous data for 2002/2003 (0.3-3.6 wt\%, Collins et al. 2009; Spilliaert et al. 2006a) and slightly higher for 2006 (0.1-2 wt\%, Collins et al. 2009). Melt inclusions from Mt. Spagnolo and 2013 lavas and 2008/2009 bombs have extremely low $\mathrm{H}_{2} \mathrm{O}$ contents $(<0.3$ wt.\%).

$\mathrm{CO}_{2}$ abundances in the glass phase span from below detection limit up to more than $5500 \mathrm{ppm}$. The highest values, measured in FS melt inclusions, are significantly higher than those previously estimated by Kamenetsky et al. (2007; 3300 ppm, Fig. 6). The $\mathrm{CO}_{2}$ contents measured in 2002/2003 and 2006 scoria MIs (124-2530 and 196-1720 ppm, respectively) are in good agreement with previous studies (e.g., Collins et al., 2009; Métrich et al., 2004; Spilliaert et al., 2006a, Fig. 6), and higher with respect to the values measured in 2008/2009 bomb MIs (88-984 ppm). The $\mathrm{CO}_{2}$ contents of 2013 and Mt. Spagnolo MIs, measured here for the first time, are also variable and in the range of those of the other eruptions (from below detection limit up to more than $1136 \mathrm{ppm}$ ). 
For each glass inclusion, $\mathrm{H}_{2} \mathrm{O}-\mathrm{CO}_{2}$ contents and major element composition were used to determine melt inclusions entrapment pressures, assuming magma volatile saturation. The solubility model of Iacono Marziano et al. (2012) was used and the calculations performed at temperatures between 1100 and $1200^{\circ} \mathrm{C}$ (with this model, the temperature effect is negligible). Results give a wide pressures range for FS (114-496 MPa), while, for the other eruptions, results are less dispersed (Fig. 6, Table SI3): Mt. Spagnolo (3-156 MPa), 2002/2003 South (7-259 MPa), 2006 (23-159 MPa), 2008/2009 (6-79 MPa), 2013 (2-82 MPa). These pressure estimates are in the same range than those previously reported for the FS, 2002/2003 and 2006 eruptions (Kamenetsky et al., 2007; Collins et al., 2009; Spilliaert et al., 2006a; respectively)], although the volatile content of the most primitive FS magma estimated in this work is significantly higher than those from previous studies. In addition, the pressure calculations use a solubility model different from previous studies and which has the advantage of being calibrated on a larger range of mafic compositions (Fig. 7 in IaconoMarziano et al., 2012).

The sulfur content of the investigated melt inclusions is extremely variable and reaches a maximum of 4238 ppm, generally higher than previous measurements (e.g., Collins et al., 2009; Corsaro and Métrich, 2016; Kamenetsky et al., 2007; Metrich and Clocchiatti, 1989; Métrich et al., 2004; Moretti et al., 2018; Spilliaert et al., 2006a-b; Figs. 7), except one 2006 MI which contain 4500 ppm (Schiavi et al., 2015). Mt. Spagnolo MIs (measured here for the first time) show the highest $\mathrm{S}$ concentrations, higher than those analyzed in MIs from FS eruption $(<3551 \mathrm{ppm}$; this study; Corsaro and Métrich 2016; Kamenetsky et al. 2007). S contents in 2002/2003 South and 2006 MIs are generally lower (134 - 3094 ppm, and 164-2957 ppm respectively) and similar to previous studies (2002/2003: 480-3470 ppm, Spilliaert et al., 2006a; 860-3567 ppm, Schiavi et al., 2015; 2006: 0-1500 ppm, Collins et al., 2009; 158-4593 ppm, Schiavi et al., 2015). The most recent 2008/2009 and 2013 MIs have a maximum of 1129 ppm S. A general trend of decreasing S with increasing $\mathrm{K}_{2} \mathrm{O}$ content is observed (Fig. 7a), except for the most primitive FS and the most evolved MIs $\left(\mathrm{K}_{2} \mathrm{O}>2.8\right.$ wt.\%). In comparison, $\mathrm{S}$ shows no clear trends with either $\mathrm{H}_{2} \mathrm{O}$ or $\mathrm{CO}_{2}$ (Figs. $\left.7 \mathrm{~b}-\mathrm{c}\right)$. 
The chlorine content is also highly variable, between 796 and $4884 \mathrm{ppm}$, the highest values being for the 2002/2003 South MIs. Compared to previous determinations, our data are either higher (Spilliaert et al., 2006) or in the same range (Collins et al., 2009; Corsaro and Métrich, 2016; Kamenetsky et al., 2007; Moretti et al., 2018; Schiavi et al., 2015). A high variability is commonly observed within the same eruption, without any clear correlation with the $\mathrm{K}_{2} \mathrm{O}$ content (Fig. SI4). The glass embayment in the 2006 olivine phenocryst ("2006-7emb", Fig. 4h) is less water-rich (0.37 wt. $\% \mathrm{H}_{2} \mathrm{O}$ ) than the $\mathrm{MI}$ in the same olivine (3.28 wt. $\% \mathrm{H}_{2} \mathrm{O}$ ), suggesting that the embayment equilibrated near the surface (Table SI3). The other two embayments ("2006-E2emb" and "2002/3S-24emb") have similar major element compositions and water concentrations, and broadly similar S and $\mathrm{Cl}$ contents, than MIs trapped in the same olivine (Table SI3). This suggests that MIs and embayments were entrapped almost concurrently at a similar (superficial) depth. $\mathrm{S}$ and $\mathrm{Cl}$ contents $\left(\mathrm{H}_{2} \mathrm{O}\right.$ and $\mathrm{CO}_{2}$ were not analyzed) of 2002/2003 matrix glasses are also very similar to MIs (Table SI3).

\section{Modeling and discussion}

Olivine-hosted melt inclusions of Etnean products erupted in the last $15 \mathrm{ka}$ record important compositional variability (Figs. 2, 3, 5, 6, 7, SI1). The prominent geochemical features emerging from this study are (i) the highly variable volatile contents, with maxima up to 6 wt. $\% \mathrm{H}_{2} \mathrm{O}, 0.60$ wt.\% $\mathrm{CO}_{2}, 0.42$ wt $\% \mathrm{~S}$, and 0.49 wt.\% $\mathrm{Cl}$ (Table SI3, Figs. 6, 7), (ii) the large variability in major element chemistry (e.g. 44.1-57.0 wt.\% $\mathrm{SiO}_{2}, 4.3-12.5$ wt.\% $\mathrm{FeO}, 1.5-11.9$ wt.\% $\mathrm{MgO}$ ), and (iii) the occurrence of systematic magma differentiation trends (Figs. 2, 5). The highest $\mathrm{CaO} / \mathrm{Al}_{2} \mathrm{O}_{3}$ ratios, $\mathrm{MgO}$ contents (Fig. 2) and volatiles concentration (maximum 7 wt.\%) of MIs trapped in Fo-rich olivines (Fo89-91) suggest that FS is the best candidate to represent the primitive parental melt of Etnean magmas (as already suggested by Kamenetsky et al., 2007). MIs trapped in less Fo-rich 
olivines (Fo88-68) from the other investigated tephra and lava samples record less primitive melts (Figs. 2, 5).

\subsection{Melt differentiation modeling}

We have modeled ascent-related crystallization using the MELTS code (Ghiorso and Sack, 1995; Smith and Asimow, 2005) previously used for Etnean magmas (e.g., Kahl et al., 2015; Mollo et al., 2015). The general objective of the simulations was to explore if the compositions of all analyzed MIs can be reproduced starting from primitive melts in FS olivines and, thus, to test if FS MIs represent a suitable parental melt for Etnean magmas in the last $15 \mathrm{ka}$. In detail, two types of simulations were carried out and a summary of the different conditions tested is provided in a supplementary table (Table SI4).

\subsubsection{Early evolution}

Type I simulations were performed to model the early differentiation of the most primitive melts observed in FS tephra. To do so, the average (4 analyses) of two MIs with the highest Mg\#, $\mathrm{CaO} / \mathrm{Al}_{2} \mathrm{O}_{3}$ ratio $\left(\mathrm{SiO}_{2}=46.5\right.$ wt. $\%, \mathrm{Al}_{2} \mathrm{O}_{3}=10$ wt. $\%, \mathrm{FeO}_{\text {tot }}=8.5$ wt. $\%, \mathrm{MgO}=11$ wt. $\%, \mathrm{CaO}=13$ wt.\%, $\mathrm{Na}_{2} \mathrm{O}=1.9$ wt. $\%, \mathrm{~K}_{2} \mathrm{O}=0.9$ wt. $\left.\%\right)$ and the highest measured $\mathrm{Cr}$ content $\left(\mathrm{Cr}_{2} \mathrm{O}_{3}=0.12\right.$ wt.\%) was used as starting composition. These most primitive MIs have an average $\mathrm{H}_{2} \mathrm{O}$ content of 4 wt.\% but, since higher contents (up to 6 wt. $\% \mathrm{H}_{2} \mathrm{O}$, Table SI3, Fig. 6) have been measured in the FS MIs, we used 5 wt. $\%$ as the starting melt $\mathrm{H}_{2} \mathrm{O}$ content for the MELTS modeling. To reproduce the deepest magmatic conditions, the simulations started from a pressure of $500 \mathrm{MPa}$ (496 is the highest pressure provided by MI, section 3.4 and Fig. 6) and the initial temperature was set at 1300 ${ }^{\circ} \mathrm{C}$ following Armienti et al. (2007; 2012) and considering the temperature of $1325-1356{ }^{\circ} \mathrm{C}$ estimated for FS magma by Coltelli et al. (2005). The final conditions were arbitrarily set at 400 
$\mathrm{MPa}$ and $1200^{\circ} \mathrm{C}$ (yielding a $\mathrm{dP} / \mathrm{dT}$ gradient of $1 \mathrm{MPa}^{\circ} \mathrm{C}^{-1}$ for the magma ascent path). An initial $f \mathrm{O}_{2}$ range between $\mathrm{NNO}+1$ to $\mathrm{NNO}+2$ [in agreement with previous estimates for primitive Etnean magmas: $\mathrm{fO}_{2} \sim \mathrm{NNO}+1.8$, Kamenetsky and Clocchiati (1996); > NNO+1; Liotta et al. (2012); > $\mathrm{NNO}+1$, Métrich et al. (2009); NNO+1 \pm 0.8 , Mollo et al. (2015)] was investigated by adjusting the $\mathrm{FeO}$ and $\mathrm{Fe}_{2} \mathrm{O}_{3}$ contents of the starting melt, and the $\mathrm{fO}_{2}$ (calculated by MELTS) was allowed to vary with progressive crystallization. Results show that, during this $\mathrm{P}-\mathrm{T}$ evolution, olivine and $\mathrm{Cr}$ spinel (present only in the simulation starting at $\mathrm{NNO}+2$ ) are the only phases crystallizing from FS melts, and that clinopyroxene is absent. Olivine ( $\left.\mathrm{FO}_{92}\right)$ matches compositions of FS crystals. However, it occurs in very low amounts $(<1 \mathrm{wt} . \%)$ indicating that most crystallization takes place at $\mathrm{T}<1200^{\circ} \mathrm{C}$ and $\mathrm{P}<400 \mathrm{MPa}$.

\subsubsection{Main crystallization stage}

The final liquids obtained in type I simulations were used as starting compositions for the type II MELTS models. These started at $1200^{\circ} \mathrm{C}$ and $400 \mathrm{MPa}$ and used variable $\mathrm{dP} / \mathrm{dT}$ of 20,5 and 3 $\mathrm{MPa}^{\circ} \mathrm{C}^{-1}$, where $\mathrm{dP}$ and $\mathrm{dT}$ mean different decrement in $\mathrm{T}$ and $\mathrm{P}$ for each step of MELTS calculation, i.e., different slopes along the magma ascent path). Different final temperatures (from 1180 to $1068{ }^{\circ} \mathrm{C}$ ) were explored, following Kahl et al. $(2011 ; 2015)$ and in agreement with direct field measurements of lava effusion temperatures in the range 980-1080 ${ }^{\circ} \mathrm{C}$ (Calvari et al., 1994), whereas final pressures were fixed at near-surface conditions (Table SI3).

Under these conditions and upon progressively decreasing $\mathrm{P}$ and $\mathrm{T}$, crystallization advances in the order olivine, spinel (progressively evolving from $\mathrm{Cr}$-spinel to Ti-magnetite), clinopyroxene and plagioclase (at pressures $<40 \mathrm{MPa}$ and for melt $\mathrm{H}_{2} \mathrm{O}$ contents $<2 \mathrm{wt} \%$ ). The crystallization series in our MELTS models are in general agreement with Mollo et al. (2015), although they used starting melt compositions less primitive than FS. Our calculated mineral assemblages are consistent with key features of Etnean magmas such as the predominance of clinopyroxene and 
olivine, the presence of plagioclase phenocrysts in the most evolved products and in all groundmasses, the occurrence of Cr-spinel in FS and Mt. Spagnolo MIs and of magnetite in the 2002-2013 MIs. Olivines produced by MELTS range between Fo92 and Fo60, covering the entire range of natural products $\left(\mathrm{Fo}_{91}\right.$ in $\mathrm{FS}$ to $\mathrm{Fo}_{68}$ in the most evolved 2013 lava) although not continuously (Fig. SI5). In MELTS simulations, olivine crystallization is generally inhibited in Carich melts (> 15 wt.\% $\mathrm{CaO}$ ), being replaced by clinopyroxene on the liquidus. However, we observe such Ca-rich MIs in FS and Mt. Spagnolo olivine phenocrysts, indicating that these melts were olivine-saturated. We may speculate that these particular Ca-rich compositions represent microscale melts, due to a dominant role of clinopyroxene dissolution-reaction-mixing (Danyushevsky et al., 2004) as suggested by Pichavant et al. (2009) and Lanzo et al. (2016) for Stromboli and Vulcano.

Clinopyroxenes calculated by MELTS have compositions very similar to those found in Mt. Spagnolo lava (Kamenetsky and Clocchiatti, 1996) and in 2001-2012 trachybasalts $\left(\mathrm{En}_{33-43}\right.$, Fs9-18,

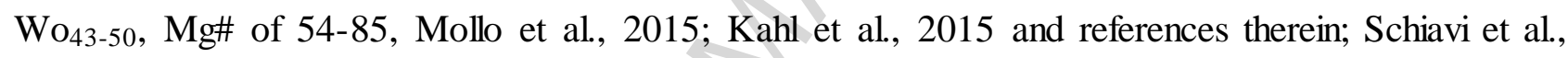
2015), and are close to clinopyroxene inclusions in FS olivine (Kamenetsky et al, 2007). The occurrence of cpx inclusions in FS olivine has yielded Kamenetsky et al. (2007) to suggest its early, deep crystallization in FS magma. Although this proposition is not supported by our MELTS modeling (see type I simulations above), recent studies (e.g., Armienti et al., 2007, 2012; Giacomoni et al., 2016) reveal that clinopyroxene crystallization occurs in Etna basalt and trachybasalts over a large $\mathrm{P}$ range (160-1380 MPa). Giacomoni et al. (2016) have suggested that some of these deep clinopyroxenes can be xenocrysts, probably derived from crystal mushes (Armienti et al., 2007) and incorporated into the uprising magma.

\subsubsection{Melt evolution along the liquid line of descent}

All MELTS simulations predict very similar variations of $\mathrm{SiO}_{2}, \mathrm{Al}_{2} \mathrm{O}_{3}, \mathrm{MgO}, \mathrm{CaO}, \mathrm{Na}_{2} \mathrm{O}$ vs $\mathrm{K}_{2} \mathrm{O}$ (Figs. 5, 8) for the residual melts along the liquid line of descent. $\mathrm{MI} \mathrm{MgO}$ and $\mathrm{CaO}$ contents (generally well reproduced) decrease, as does the $\mathrm{CaO} / \mathrm{Al}_{2} \mathrm{O}_{3}$ ratio, while the $\mathrm{SiO}_{2}$ and alkali 
contents increase (Figs. 5, 8) as a result of crystallization of olivine + clinopyroxene + spinel + plagioc lase.

The variability in the $\mathrm{H}_{2} \mathrm{O}$ content of inclusions for a given as well as between different eruptions suggests different degassing paths (Fig. 9). For instance, the FS MIs show highly variable $\mathrm{H}_{2} \mathrm{O}$ contents at nearly constant $\mathrm{K}_{2} \mathrm{O}$, suggesting near-adiabatic ascent that allowed this highly primitive magma to reach the surface without significant differentiation (Coltelli et al., 1998; 2005). The type II MELTS simulations with a high $\mathrm{dP} / \mathrm{dT}$ ratio $\left(20 \mathrm{MPa}^{\circ} \mathrm{C}^{-1}\right)$ and a final temperature of $1180{ }^{\circ} \mathrm{C}$ reproduces well the $\mathrm{H}_{2} \mathrm{O}$ degassing trend observed in these MIs (red curves in Fig. 9). Conversely, the Mt. Spagnolo, 2008/2009 and 2013 MIs present very low $\mathrm{H}_{2} \mathrm{O}$ contents and variable $\mathrm{K}_{2} \mathrm{O}$ (Fig. 9), which may suggest early $\mathrm{H}_{2} \mathrm{O}$ degassing, prior to significant crystallization. However, the Mt. Spagnolo MIs are characterized by decoupled volatile abundances, with high $\mathrm{CO}_{2}$ (up to $2726 \mathrm{ppm}$ ), S (up to $4238 \mathrm{ppm}$ ), and $\mathrm{Cl}$ (up to $4273 \mathrm{ppm}$ ) and low $\mathrm{H}_{2} \mathrm{O}(<0.3$ wt.\%). This could reflect trapping of an initially volatile-rich melt followed by $\mathrm{H}_{2} \mathrm{O}$ loss due to $\mathrm{H}^{+}$diffusion in the host olivine during cooling (Sobolev et al., 1991; Gaetani et al, 2012). Alternatively, $\mathrm{H}_{2} \mathrm{O}$ could have been stripped from the melt at depth by $\mathrm{CO}_{2}$ flushing. The former hypothesis appears more realistic due to the slow cooling experienced by the Mt. Spagnolo lava flow. It is also worth reminding that $\mathrm{H}^{+}$diffusion is particularly effective at high temperatures and low pressures (Gaetani et al., 2012), i.e., under lava emplacement conditions. Thermobarometric data for Mt. Maletto lavas, similar to the Mt. Spagnolo (Giacomoni et al., 2016; Kamenetsky and Clocchiatti, 1996), reveal a deep intratelluric crystallization episode in those Etnean magmas. Therefore, it is most likely that crystallization of Mt. Spagnolo lavas did not take place only at the near surface conditions implied by the low $\mathrm{H}_{2} \mathrm{O}$ contents of MIs. However, because of $\mathrm{H}_{2} \mathrm{O}$ loss, the high-pressure crystallization/trapping stage that affected the magmas is not preserved in the Mt. Spagnolo MIs. The 2013 MIs are also from a lava flow and may similarly have suffered post-entrapment $\mathrm{H}_{2} \mathrm{O}$ loss. However, their relatively low $\mathrm{CO}_{2}(<720 \mathrm{ppm}$, with an outlier at $1136 \mathrm{ppm})$ and $\mathrm{S}$ contents $(<580$ 
ppm) speak for volatile degassing preceding entrapment, as is the case for the 2008/2009 MIs which, nevertheless, come from a strombolian deposit.

The 2001 to 2007 MIs show progressive degassing during melt differentiation (i.e. decreasing $\mathrm{H}_{2} \mathrm{O}$ contents with increasing $\mathrm{K}_{2} \mathrm{O}$ contents Fig. 9), which are well reproduced by the fractional crystallization of the parent $\mathrm{FS}$ melt with $\mathrm{dP} / \mathrm{dT}$ trajectories between 3 and $5 \mathrm{MPa}{ }^{\circ} \mathrm{C}^{-1}$ and final temperatures of 1122 and $1068{ }^{\circ} \mathrm{C}$ respectively (blue and green curves in Fig. 9). The water contents of 2008/2009 and 2013 MIs are also generally reproduced by the lowest pressure segments of these two curves, probably following a superficial low-pressure decompression. Fractional crystallization along a dP/dT between 3 and $5 \mathrm{MPa}{ }^{\circ} \mathrm{C}^{-1}$, ending at temperatures of $\sim 1100{ }^{\circ} \mathrm{C}$, can, therefore, generate most of the $\mathrm{H}_{2} \mathrm{O}-\mathrm{K}_{2} \mathrm{O}$ trends observed in recent Etnean MIs (2001-2013). Changes in $\mathrm{dP} / \mathrm{dT}$ and final temperatures within a single eruption could reflect the tapping of individual magma batches with different ascent histories, caused by provenance from different magma accumulation zones, vertical and lateral changes in the density of basement rocks as well as variable volatile contents and gas fractions (Armienti et al., 2012).

\subsubsection{Redox control on melt evolution}

The large spread in $\mathrm{FeO}_{\text {tot }}$ (and, to a lesser extent, $\mathrm{TiO}_{2}$ ) contents in MIs potentially reflects variations of redox conditions in addition to melt differentiation (e.g., Figs. 5; 10), which in turn control the proportion of spinel crystallization and the $\mathrm{FeO}_{\mathrm{tot}} / \mathrm{MgO}$ ratio of the melt (Pichavant et al., 2002 and reference therein).

For instance, spinel (both Fe-Ti oxide and $\mathrm{Cr}$-spinel) crystallization in Etnean magmas can vary from one eruption to the other and during the same eruption as well. Cr-rich spinel is commonly observed to be included within FS (and Mt. Spagnolo) olivine phenocrysts (Table SI1), consistent with its early appearance from a FS parental liquid in MELTS models, which requires oxidizing conditions. Pichavant et al. (2002) found that melts produced under very oxidizing conditions $(\Delta \mathrm{NNO}>+2.5)$ have $\mathrm{FeO}_{\text {tot }} / \mathrm{MgO}$ that is constant or decreases with increasing crystallization, 
which indicates preferential partitioning of $\mathrm{Fe}$ toward the mineral phases (mainly magnetite) relative to $\mathrm{Mg}$. This behavior is evident in FS and Mt. Spagnolo MIs. In the first ones, the constancy in $\mathrm{FeO}_{\text {tot }} / \mathrm{MgO}$ ratio and $\mathrm{FeO}_{\text {tot }}$ content, and the decrease of $\mathrm{MgO}$ (Figs. 5d-e, 10) could be ascribed to olivine and $\mathrm{Cr}(\mathrm{Mg})$-spinel crystallization, well reproduced by the MELTS models at high initial $\mathrm{fO}_{2}(\mathrm{NNO}+2)$ conditions and with high $\mathrm{dP} / \mathrm{dT}$ ratio $\left(20 \mathrm{MPa}{ }^{\circ} \mathrm{C}^{-1}\right)$, although calculated phase proportions ( $<1$ for ol and $<0.3 \mathrm{wt} \% \%$ for $\mathrm{Cr}$-spinel) are lower than those found in natural rocks.

Differently from FS, MIs of Mt. Spagnolo (this study and Kamenetsky and Clocchiatti, 1996), Mt. Maletto (Kamenetsky and Clocchiatti, 1996) and Frumento delle Concazze (FdC, Corsaro and Métrich, 2016) eruptions show a different trend, with a stronger decrease of $\mathrm{FeO}_{\text {tot }}$ and $\mathrm{MgO}$ (Figs. 5d-e) and an increase of $\mathrm{TiO}_{2}$ (Fig. 5g). In addition, Mt. Maletto and Mt. Spagnolo MIs have a $\mathrm{FeO}_{\text {tot }} / \mathrm{MgO}$ ratio constant or decreasing with $\mathrm{K}_{2} \mathrm{O}$, while the $\mathrm{FeO}_{\text {tot }} / \mathrm{MgO}$ ratio of $\mathrm{FdC}$ increases slightly during melt evolution (Fig. 10). These behaviors are partially reproduced by a MELTS model with low $\mathrm{dP} / \mathrm{dT}$ ratio $\left(\mathrm{dP} / \mathrm{dT}=2 \mathrm{MPa}{ }^{\circ} \mathrm{C}^{-1}\right)$, only when starting from a $\mathrm{fO}_{2}>\mathrm{NNO}+3$ (black curve in Fig. 10). Such extremely oxidizing redox conditions are needed to let MELTS crystallizing abundant spinel (>1 wt.\%), relatively early on the liquidus. However, this curve is not totally coincident with all the MIs of Mt. Spagnolo, because this MELTS model is associated with an important decrease in $\mathrm{fO}_{2}$ conditions (2 log units) during crystallization. The abundance of $\mathrm{Cr}$-spinel inclusions in Mt. Spagnolo olivine corroborates spinel crystallization as a mechanism to generate the $\mathrm{FeO}_{\text {tot }}$ and $\mathrm{MgO}$ decrease observed in these inclusions (Figs. 5d-e), while a constant high oxygen fugacity seems requested to maintain constant or to slightly decrease the $\mathrm{FeO}_{\text {tot }} / \mathrm{MgO}$ ratio during crystallization. An oxygen fugacity $>\mathrm{NNO}+3$ (to trigger spinel crystallization) seems unrealistically high for Etna basalts, the highest $f \mathrm{O}_{2}$ estimated for Etna being $\sim \mathrm{NNO}+1.8$ (Kamenetsky and Clocchiatti, 1996; Mollo et al. 2015). Yet, high oxygen fugacities are certainly required to account for early spinel crystallization and the high sulfur contents of FS, and particularly Mt. Spagnolo MIs (Jugo, 2009). Indeed, high $f_{\mathrm{O}_{2}}$ conditions were calculated for FS and 
Mt. Spagnolo using the olivine-spinel oxybarometer of Ballhaus et al. (1991) and the composition of Cr-spinel inclusions inside MI/ol (Table SI1): oxygen fugacities of respectively $\sim 1.6$ and $\sim 2$ units $\log$ above the buffer NNO were obtained for $\mathrm{T}$ between $1170{ }^{\circ} \mathrm{C}$ (estimated for Mt. Spagnolo by Kamenetsky and Clocchiatti 1996) and $1300^{\circ} \mathrm{C}$.

Green and blue curves in Figs. 5 to 10 describe the evolution of a FS magma, associated to important $\mathrm{FeO}_{\text {tot }}$ and $\mathrm{MgO}$ and $\mathrm{FeO}_{\text {tot }} / \mathrm{MgO}$ variations. These variations, in some case, are less important than really shown by the Etnean MIs. On the contrary, the $\mathrm{FeO}_{\text {tot }} / \mathrm{MgO}$ in the residual melt predicted by MELTS models with $\mathrm{dP} / \mathrm{dT}$ ratios of $3 \mathrm{MPa}^{\circ} \mathrm{C}^{-1}$ (blue curves) are more pronounced than those really calculated for 2001-2013 MIs, suggesting that variations in $f \mathrm{O}_{2}$ are less significant than those calculated by MELTS.

Variable $\mathrm{fO}_{2}$ conditions, associated to variable $\mathrm{Fe}$-spinel and clinopyroxene crystallization, are necessary to justify the large variability in $\mathrm{FeO}_{\text {tot }}$ (and $\mathrm{TiO}_{2}$ ) contents observed in the MIs from 2001 to 2013 eruptions (Figs. 5d-e-g, 10). On the one hand, no or slight spinel (and clinopyroxene) crystallization is needed to explain $\mathrm{FeO}_{\text {tot }}$ enrichment in the melt above 11 wt.\% (Fig. 5e), while, on the other hand, abundant spinel and clinopyroxene crystallization at temperatures lower than 1070 ${ }^{\circ} \mathrm{C}$ induces $\mathrm{FeO}_{\text {tot }}$ to decrease in the melt to $8 \mathrm{wt} . \%$. Such a variability in spinel (and clinopyroxene) crystallization is obtained with MELTS simulations by changing the initial oxygen fugacity from $\mathrm{NNO}+1$ to $\mathrm{NNO}+2$, and the $\mathrm{dP} / \mathrm{dT}$ ratios between 3 and $5 \mathrm{MPa}{ }^{\circ} \mathrm{C}^{-1}$.

Anyway, the lowest $\mathrm{FeO}_{\text {tot }}$ contents $(\sim 4$ wt.\%) of the 2013 MIs is not obtained by the performed MELTS models (Fig. 5e). These MIs show, in Fig. 10, a constant $\mathrm{FeO}_{\text {tot }} / \mathrm{MgO}$ ratio during melt evolution, probably due to abundant magnetite precipitation at constant $f \mathrm{O}_{2}$.

\subsection{Depth of storage and degassing pattern of the erupted magmas}

We used the $\mathrm{H}_{2} \mathrm{O}-\mathrm{CO}_{2}$ solubility model of Iacono-Marziano et al. (2012), specifically suited for alkaline mafic melts, to estimate pressures of entrapment (see section 3.4) of melt inclusions (Fig. 
6). Bearing in mind that (i) estimated $\mathrm{H}_{2} \mathrm{O}$ and $\mathrm{CO}_{2}$ in the glass phase of MI represent the minimum volatile budget of the trapped melts, and (ii) investigated MIs may also have high $\mathrm{S}$ and $\mathrm{Cl}$ contents, the estimated pressures have to be regarded as the minimum ones. To convert the entrapment pressures into (minimum) pre-eruptive magma storage-crystallization depths, we used an average rock density value of $2.65 \mathrm{~g} \mathrm{~cm}^{-3}$, taking into account the different density of the lithologies in the first $22 \mathrm{~km}$ of the Etnean basement: from 2.57 to $2.70 \mathrm{~g} \mathrm{~cm}^{-3}$ (Corsaro and Pompilio, 2004b).

Studied melt inclusions were entrapped at different depths in the Etnean plumbing system down to $\sim 19 \mathrm{~km}$ below crater level ("bcl"). The deepest MIs are in the olivine from FS eruption, which show the larger range of entrapment pressures $(\sim 4-19 \mathrm{~km} \mathrm{bcl})$. The inclusions from the other eruptions (Mt. Spagnolo, 2002/2003 South, 2006, 2008/2009 and 2013) were entrapped in a narrower range of pressures (0-259 MPa), indicating shallower depths, generally lower than $10 \mathrm{~km} \mathrm{bcl}$ (Table SI3 and Fig. 6). The minimum entrapment depths are relatively similar to those determined by previous studies (e.g., Collins et al., 2009; Kamenetsky et al., 2007; Spilliaert et al., 2006a), although we used different $\mathrm{H}_{2} \mathrm{O}-\mathrm{CO}_{2}$ solubility model (see 3.4 section).

We used the model of Iacono-Marziano et al. (2012) to simulate the degassing of the deepest $(\sim 15$ $19 \mathrm{~km} \mathrm{bcl}$ ), volatile-rich primitive $\mathrm{FS}$ magma, with an initial $\mathrm{XCO}_{2}$ of 0.7-0.8 (calculated from the highest $\mathrm{H}_{2} \mathrm{O}$ and $\mathrm{CO}_{2}$ contents in MIs). Considering that the highest $\mathrm{CO}_{2}$ contents in the FS inclusions are affected by a large error (> $800 \mathrm{ppm}$ ), two distinct initial conditions were used to simulate volatile degassing both in closed and open system conditions: $\sim 6000$ ppm $\mathrm{CO}_{2}-4$ wt.\% $\mathrm{H}_{2} \mathrm{O}$ (the average $\mathrm{H}_{2} \mathrm{O}$ content of MIs FS) - and $5000 \mathrm{ppm} \mathrm{CO}_{2}-5$ wt. $\% \mathrm{H}_{2} \mathrm{O}$ (the same values used for MELTS fractional crystallization modeling), with the aim of reproducing the large range of $\mathrm{H}_{2} \mathrm{O}-\mathrm{CO}_{2}$ concentrations shown by MIs, by simulating volatile degassing both in closed and open system conditions. In the modeling of a closed system degassing, we varied the excess of fluid phase (i.e. the amount of fluid phase initially coexisting with the magma). The models in closed system conditions with excess of fluid phase between 0 and 20 wt.\% define an area in the $\mathrm{CO}_{2}-\mathrm{H}_{2} \mathrm{O}$ 
plot (grey in Fig. 6) that well describes the degassing of the primitive FS melt by reproducing the successive polybaric entrapment of most of FS inclusions. This area (grey in Fig. 6) also encloses some MIs of the 2001-2006 eruptive period (this study; Collins et al., 2009; Métrich et al,, 2004; Spilliaert et al, 2006a), suggesting that they may have derived from a volatile-rich, FS-type melt, in terms of $\mathrm{H}_{2} \mathrm{O}$ and $\mathrm{CO}_{2}$ contents.

An additional trend (violet area in Fig. 6) describes the degassing of another group of more evolved, partially $\mathrm{H}_{2} \mathrm{O}$ and $\mathrm{CO}_{2}$ degassed MIs entrapped at depth $<250 \mathrm{MPa}$ (mainly from 2002/2003 South and subordinately from 2006 and FS tephra), which are $\mathrm{CO}_{2}$-richer (probably due to some flushing episode), and/or $\mathrm{H}_{2} \mathrm{O}$ poorer than the MIs belonging to the first group. This degassing trend is modeled starting from the average highest volatile contents in the studied MIs from 2002/2003 South eruption $\left(\mathrm{H}_{2} \mathrm{O}=2.3 \pm 0.1\right.$ wt. $\%, \mathrm{CO}_{2}=2220 \pm 270$ ppm $)$.

A third group of melt inclusions from 2013, 2008/2009 and Mt. Spagnolo eruptions, together with some from 2002/2003 South and 2006 (Collins et al. 2009; Spilliaert et al. 2006a), are $\mathrm{H}_{2} \mathrm{O}$ depleted and anomalously enriched in $\mathrm{CO}_{2}$ (up to 2720 ppm, Fig. 6). The maximum estimated entrapment depth of these MIs is comparable to that estimated for the second group (Fig. 6).

We already mentioned (section 3.4) that Mt. Spagnolo MIs may have suffered post-entrapment $\mathrm{H}_{2} \mathrm{O}$ loss and therefore are not well suited to retrieve entrapment depths. However, several other MIs from this study and from the literature clearly suggest the $\mathrm{H}_{2} \mathrm{O}$ loss from the melt and the enrichment in $\mathrm{CO}_{2}$ at a depth of 8-10 km (i.e., passing from the MIs of the first group to those of the second and from those of the second to those of the third; Fig. 6). On the basis of recent decompression experiments of mafic melts, these high $\mathrm{CO}_{2}$ contents can be explained by $\mathrm{CO}_{2}$ oversaturation generated by (kinetic) disequilibrium melt degassing during magma ascent (Le Gall and Pichavant, 2016; Pichavant et al., 2013), even if in the case of Mt. Etna the gas discharges of the volcano do not display evidences of degassing far from equilibrium (Paonita et al., 2012). 
Alternatively, the need for 20 wt.\% excess fluid phase to account for volatile contents in MIs suggests that an extremely high amount of fluid phase could coexist with the magma, in agreement with the massive volatile emissions observed at Mt. Etna (Aiuppa et al., 2008). In particular, the addition of $\mathrm{CO}_{2}$-rich fluids to the magma has been previously invoked ("COO fluxing"; e.g., Collins et al., 2009; Ferlito and Lanzafame, 2010; Spilliaert et al., 2006a; and references therein), with the excess $\mathrm{CO}_{2}$, deriving either from the degassing of a deep magmatic body, or from the interaction of the magma with sedimentary carbonates (Aiuppa et al., 2017; Chiodini et al., 2011). The latter hypothesis is corroborated by the estimated depth of the magma ponding zone identified in this study, but also by Spilliaert et al., (2006a), at which the $\mathrm{CO}_{2}$ enrichment mainly occurs: 8-10 km bcl, would be in the Hyblean carbonates (Finetti et al., 2006; Spilliaert et al, 2006a; and references therein).

Differently, FS magma seems to have a deeper accumulation zone at $15-19 \mathrm{~km} \mathrm{bcl}$, probably at the boundary between the crystalline basement and the Hyblean carbonates. The depths of these two ponding zones are in relatively good agreement with those estimated by the seismic tomography for the fossil magma chambers (>12 km bcl; e.g. FS eruption), and for the current one $(6 \mathrm{~km} \mathrm{bcl})$ at Etna (Aloisi et al., 2002).

Instead, no clear evidence exists about the occurrence of Middle to Late Triassic sulfate rocks at the depths of entrapment of FS MIs; however evaporitic rocks, belonging to the Late Messinian Gessoso-Solfifera Formation, widespread in the nearby Caltanissetta Basin (Finetti et al. 2006; Lentini, 1982), may be encountered by Etnean magmas during their ascent to the surface, and contribute to the high $\mathrm{S}$ and low $\mathrm{SiO}_{2}$ contents of Mt. Spagnolo MIs, associated to the particularly high oxygen fugacity (see sections 4.1.4 and 5).

Indeed, the S contents of the melt inclusions characterized in this study are not clearly correlated with their estimated entrapment pressures (Fig. 11a), as observed in Spilliaert et al. (2006b). In particular, several melt inclusions from Mt. Spagnolo, 2002/2003 South and 2006 products, show S 
contents > $2000 \mathrm{ppm}$, although they were entrapped at pressure below $150 \mathrm{MPa}$ (Fig. 11a). This suggests that depressurization is not the principal parameter controlling $\mathrm{S}$ degassing in the hydrous Etnean magmas, and therefore the S content of MIs.

The redox conditions varying between different eruptions and, to a lesser extent, during the same eruption, seem to play a crucial role in determining $S$ behavior in Etnean magmas. The most primitive MIs show early spinel crystallization and high $\mathrm{S}$ contents (principally in Mt. Spagnolo), both due to strongly oxidizing redox conditions (section 4.1.4; Jugo, 2009). The more evolved MIs (belonging to the 2001-2013 eruptive period) show variable extents of late spinel crystallization that probably reflects lower and variable $\mathrm{fO}_{2}$ conditions (Fig. 10). The $\mathrm{S}$ content of these inclusions clearly decreases with differentiation (Fig. 7), suggesting that differentiation is a critical process in controlling $\mathrm{S}$ degassing, probably by modifying magma redox conditions.

Differently from $\mathrm{S}, \mathrm{Cl}$ seems to be enriched in the melt in the upper part of the plumbing system (the last $100 \mathrm{MPa}$, Fig. 11b), suggesting an incompatible behavior during melt differentiation, which is however not illustrated by a clear correlation with the $\mathrm{K}_{2} \mathrm{O}$ content (Fig. SI4). Coupled processes of degassing and crystallization-driven enrichment could explain these features. We also note that the variable concentration of $\mathrm{Cl}$ in Etnean melts has been ascribed to the upward migration of deep Cl-rich fluids (Ferlito et al., 2014; and reference therein), or as a consequence of several interactions and connections between distinct magma pockets within Etna's shallow plumbing system (Corsaro and Metrich, 2016; Kahl et al., 2011). Furthermore, Rizzo et al. (2013) assume the variable isotopic $\mathrm{Cl}$ and $\mathrm{Cl} / \mathrm{K}$ ratio, in rocks and gases of 2008-2011 periods, as representative of a typical depleted mantle magma contaminated by altered oceanic crust.

In conclusion, despite the possible different interpretations, volatile contents in MIs strongly suggest important magma degassing during magma evolution and ascent. $\mathrm{H}_{2} \mathrm{O}, \mathrm{CO}_{2}$, and $\mathrm{Cl}$ degassing are likely to be mainly driven by magma decompression, while $\mathrm{S}$ degassing seems to be related to melt differentiation and redox conditions. This degassing translates into significant gas 
emissions, which are at present regularly observed at Etna (e.g. Aiuppa et al., 2008; Allard et al, 2006).

\section{Additional processes contributing to magmas heterogeneity}

Even if MELTS fractional crystallization models (section 4.1) seem able to reproduce most of major elements compositions of MIs starting from an $\mathrm{H}_{2} \mathrm{O}$-rich FS parental magma, some chemical features require additional interpretations. In particular, FS melt inclusions display $\mathrm{SiO}_{2}$ contents higher than the less primitive Mt. Spagnolo ones, these latter more variable and slightly higher in $\mathrm{CaO}$ than FS (Figs. 5a, c). Several melt inclusions from the recent eruptions (1995-2008) also show lower $\mathrm{SiO}_{2}$ and slightly higher $\mathrm{CaO}$ contents (Figs. 5a, c). These trends can be difficulty explained by the only crystallization of olivine and clinopyroxene, MELTS simulations predicting indeed a clear $\mathrm{SiO}_{2}$ increase during magma evolution, and conversely a continuous and sharp decrease of $\mathrm{CaO}$ (Figs. 5a-c). This has also to be considered together with the already (section 3.4) $\mathrm{S}$ content of the MIs of FS, which is lower than that of Mt Spagnolo. This could, therefore, suggest the addition of a sulfate component to the magma, possibly deriving by assimilation of S-rich evaporitic rocks of Messinian age, widely outcropping in Sicily and very likely occurring within the sedimentary basement of Mt. Etna. This assimilation enriches the melt in $\mathrm{S}$ and to a lesser extent in $\mathrm{CaO}$, while decreases its silica content (Figs. SI6a-b), and strongly oxidizes the magma (Iacono-Marziano et al. 2017). Being this a local process that depends on the physical path followed by each magma upon its ascent, and also on its temperature and ascent rate, sulfate assimilation could therefore account for (i) the changes in the redox conditions (and the resulting different timings and amounts of spinel crystallization) observed between the different eruptions (section 4.1.4, Fig. 10), but also during a single eruption, and (ii) the large dispersion in the $\mathrm{SiO}_{2}$ content, of which only the highest $\mathrm{SiO}_{2} / \mathrm{K}_{2} \mathrm{O}$ values are reproduced by MELTS (Figs. 5). 
Another crustal process that has been reported in previous studies on Etna is the magma mixing in the shallow plumbing system, in order to explain the compositional variation of products erupted after 1970's (e.g., Corsaro and Pompilio, 2004a; Métrich et al., 2004), as well as, for the Mt. Frumento delle Concazze lava (Corsaro and Métrich, 2016; and references therein). The occurrence in the Mt. Spagnolo lava of the large compositional range of olivine (Fo70-88), some of which with reverse zoning (section 2.1), could indeed indicate the presence of interactions between two magma batches with different compositions originating from dissimilar fractional crystallization-induced melt evolutions. Episodes of deep mixing between a primitive melt and one resulting by the incongruent melting (Danyushevsky et al., 2004) of clinopyroxene- or plagioclase-rich cumulates could be the cause of (i) the high $\mathrm{CaO}$ contents of MIs from FS (this study, Corsaro and Métrich, 2016) and Mt. Maletto (Kamenetsky and Clocchiatti, 1996), and (ii) the enrichment of $\mathrm{Ba}$, Sr and Eu observed in MIs of 2001-2006 products (Schiavi et al., 2015).

Alternatively, numerous authors have invoked the occurrence of mantle processes to account for the compositional variability of Etna products. On this view, Correale et al. (2014) concluded that the modeling of the whole-rock compositions of Etnean volcanics from the last 15 ka requires pristine melts having significant differences in some major oxides, especially $\mathrm{Na}_{2} \mathrm{O}$, which can be explained by variable melting degrees of a single mantle source, followed by crystallization. Even if the study of Correale et al. (2014) on whole rocks can be influenced, in the case of FS, by a possible enrichment of olivine crystals, their results apply to MI compositions too. Inspection at Fig. $5 \mathrm{f}$ shows, in fact, that $\mathrm{Na}_{2} \mathrm{O}$ contents of FS and Mt. Spagnolo MIs do not fit with a single liquid descent line, with FS requiring a pristine melt depleted in $\mathrm{Na}_{2} \mathrm{O}$. According to Correale et al. (2014), this would be due to a large melting degree generating the FS pristine melt. However, this would not account for the similarity in the $\mathrm{CaO}$ content of FS (13-15 wt.\%) and Mt. Spagnolo (6-16 wt.\%) melt inclusions, as $\mathrm{CaO}$ should increase with increasing source partial melting (Correale et al., 2014). 
The patterns of trace elements provide further evidences about the occurrence of variable degrees of mantle melting. During crystal fractionation of olivine-spinel-clinopyroxene-plagioclase from FS magma (this study, Kamenetsky et al., 2007 for trace elements composition), MELTS models show an enrichment in the melt in incompatible trace elements (Figs. SI7). This enrichment is, however less important than that observed in natural olivine-hosted MIs (Collins et al., 2009; Kamenetsky et al., 2007; Rose-Koga et al., 2012; Schiavi et al., 2015, Figs. SI7; except for Y, Yb, and Zr). This suggests that the degree of enrichment of the parental melt cannot be the same one for all the eruptions but pristine melts with variable contents of trace elements have to exist.

The involvement of metasomatizing phases (fluid or melts) has also been recognized at Etna by several authors. Kamenetsky and Clocchiatti (1996) invoked a progressive multi-stage melting and subsequent metasomatism of the upper mantle peridotite due to reaction with a penetrating or percolating fluid/melt. Corsaro and Métrich (2016) suggest a variable involvement of clinopyroxenitic lithology and $\mathrm{Rb}-{ }^{87} \mathrm{Sr}-\mathrm{Cl}$-rich fluid components in the mantle. In particular, the variability of the $\mathrm{Rb} / \mathrm{Th}$ ratios, moving from a value of 2 in 2002/2003 MIs up to 9.7 in MIs of $F S$ and 2001 eruptions estimated by Kamenetsky et al. (2007) and Schiavi et al. (2015), cannot be explained by melting and/or crystallization (Figs. SI7c-d), due to the similar partition coefficients of these two elements. Their different affinity with aqueous fluids, coupled to the high contents of these elements, resembling those typical of arc magmatism, address to a contribution of a crustal slab-derived component in the mantle source producing Etnean magmas in the last $15 \mathrm{ka}$ (Corsaro and Métrich, 2016; Tonarini et al., 2001). Accordingly, the heterogeneous Nd-Sr-Ba elemental contents $(28-67,396-1573,255-817 \mathrm{ppm})$ and isotopic features $\left({ }^{144} \mathrm{Nd} /{ }^{143} \mathrm{Nd}\right.$ : between $0.512836 \pm 6$ of FS and $0.512908 \pm 5$ of Mt. Spagnolo; ${ }^{87} \mathrm{Sr} /{ }^{86} \mathrm{Sr}$ : $0.703317 \pm 6$ for Mt. Spagnolo up to $0.703910 \pm 6$ for FS) were attributed by Correale et al. (2014) to different melting degree of a mantle source (variable) - metasomatized by crustal fluids. On this ground, Correale et al. (2014) showed that the effects of the metasomatism largely differ depending on the considered element and its mobility, 
thus the trace element patterns can be modified even if the major oxide compositions of the pristine melts are almost unaffected.

\section{Concluding remarks}

Olivine hosted melt inclusions were accurately selected from (trachy)-basaltic tephra and lavas formed during Etnean eruptions of the last $15 \mathrm{ka}$ : in particular, from the oldest and most primitive magmas (Mt. Spagnolo basalt and FS picro-basalt) up to more evolved trachybasalts erupted during the paroxysmal event of April 2013, and from 2002/2003 South, 2006 and 2008/2009 eruptions. All the MIs were characterized for their major elements compositions and volatiles contents by electron microprobe, ion probe, and/or infrared spectroscopy, using the same conditions to insure an internal consistency in this new dataset. These results were interpreted in terms of the principal magmatic processes, using MELTS code and $\mathrm{H}_{2} \mathrm{O}-\mathrm{CO}_{2}$ solubility models, and integrating literature data.

Here the principal remarks from this study:

- FS tephra entrapped, in Mg-rich olivine (Fo89-91), the most undegassed and primitive melt inclusions $(\mathrm{Mg \# =} 67-70)$ among the investigated products of the last $15 \mathrm{ka} \cdot \mathrm{H}_{2} \mathrm{O}$ and $\mathrm{CO}_{2}$ contents $\left(\mathrm{H}_{2} \mathrm{O}\right.$ up to 6 wt.\%, $\mathrm{CO}_{2}$ up to more than $\left.5000 \mathrm{ppm}\right)$ of the glass phase, with the highest values indicating high pressure of crystallization $(496 \mathrm{MPa}$, i.e. a depth of entrapment of $19 \mathrm{~km} \mathrm{bcl}$ ), suggest an important volatile source in the deepest magmatic system. FS magma experienced a rapid ascent (associated to a high decompression, $\mathrm{dP} / \mathrm{dT} \geq$ $20 \mathrm{MPa}{ }^{\circ} \mathrm{C}^{-1}$ ) that led to $\mathrm{H}_{2} \mathrm{O}$ and $\mathrm{CO}_{2}$ degassing without substantial melt differentiation and $\mathrm{S}$ degassing. The whole rock composition rather suggests olivine accumulation in the melt. The rapid ascent, experienced in closed system conditions, probably allowed FS primitive magma to reach the surface and to be erupted explosively. 
- The most recent trachybasalts of 2001-2013 eruptions host melt inclusions progressively more evolved and degassed, and entrapped in a shallower plumbing system $(0-10 \mathrm{~km} \mathrm{bcl})$. The composition of MIs of these eruptions indicates that Etnean magmas generally underwent a more gradual decompression $\left(\mathrm{dP} / \mathrm{dT}<5 \mathrm{MPa}{ }^{\circ} \mathrm{C}^{-1}\right)$ than in the case of $\mathrm{FS}$ eruption, allowing a more important melt differentiation and $\mathrm{H}_{2} \mathrm{O}-\mathrm{CO}_{2}$ degassing in closed system than FS magma.

- The chemical variability observed in the investigated Etnean melt inclusions (e.g., $\mathrm{FeO}_{\text {tot }}$ : 4.3-12.5 wt.\%; $\mathrm{CaO}: 3.1-15.8$ wt.\%; $\mathrm{MgO}: 1.5-11.9$ wt.\%, $\mathrm{K}_{2} \mathrm{O}: 0.6-5.8$ wt.\%) and in the volatiles (0-7 wt.\%) is mainly attributed (on the basis of a petrogenetic modeling using MELTS code) to the effect of melt differentiation of the parental $\mathrm{H}_{2} \mathrm{O}$-rich FS magma, due to fractional crystallization of spinel $(\mathrm{Cr}-\mathrm{Mg}$-rich to Ti-magnetite $)+$ olivine + clinopyroxene \pm plagioclase in a highly oxidized system $\left(\mathrm{fO}_{2}\right.$ between $\mathrm{NNO}+1$ and $\left.\mathrm{NNO}+2\right)$. The MELTS simulations, performed in T-P range of $1300-1050{ }^{\circ} \mathrm{C}$ and $500-0.1 \mathrm{MPa}$, and with variable $\mathrm{dP} / \mathrm{dT}$ ratio, generally yield to the decrease in $\mathrm{MgO}, \mathrm{H}_{2} \mathrm{O}, \mathrm{CaO} / \mathrm{Al}_{2} \mathrm{O}_{3}$ ratio, and the increase of alkali (especially $\mathrm{K}_{2} \mathrm{O}$ ), as outlined in MIs from FS to the most evolved and degassed of 2013. The mineral compositions predicted by MELTS models are generally consistent with those observed in Etnean products.

- MIs in Mt. Spagnolo olivine phenocrysts (Fo82-88) have primitive features in terms of their major elements (although to a lesser extent than FS MIs), but present the highest S contents (4238 ppm), variable $\mathrm{CO}_{2}$ contents $(0-2720 \mathrm{ppm})$ and low $\mathrm{H}_{2} \mathrm{O}(<0.3$ wt.\%), probably due to a $\mathrm{H}^{+}$diffusion trough olivine crystals imposed by the slower cooling conditions, thus unreliable to calculate a crystallization pressure. The particular Mt. Spagnolo melt inclusions (partially degassed and less primitive than FS MIs) could be originated through the differentiation of a $\mathrm{FS}$ melt under very oxidizing conditions $\left(\mathrm{fO}_{2}>\mathrm{NNO}+2\right)$, or alternatively magma mixing episodes between a primitive FS-type melt and an evolved residual magmatic body at shallow depth, as inferred by previous studies (e.g. Corsaro and 
Métrich, 2016; Kahl et al., 2015). This would also agree with the reverse zoning of olivine crystals. The highest $\mathrm{S}$ contents of these MIs and the high oxygen fugacity could alternatively suggest the assimilation of sedimentary sulfates during magma ascent or ponding.

Although the results of this study suggest that most of the first-order features of the Etnean magmas erupted in the last $15 \mathrm{ka}$ can be modeled by differentiation through fractional crystallization and degassing, we stress that the interpretation of some geochemical features (i.e., large variability in $\mathrm{Al}_{2} \mathrm{O}_{3}, \mathrm{Na}_{2} \mathrm{O}, \mathrm{CO}_{2}, \mathrm{Cl}$, isotopic ratios and trace elements) requires the contribution of additional mechanisms from the crustal system or the mantle source. In the former case, this encompasses assimilation, volatile flushing, and magma mixing. In the latter case, the heterogeneity of the mantle source and variable degrees of mantle melting (as already proposed by numerous previous studies e.g., Correale et al., 2014; Viccaro et al., 2011) can produce some compositional differences in the parental melt at Etna, especially concerning the abundances of fluid mobile elements.

\section{Acknowledgments}

This work is part of the PhD thesis of E. Gennaro, which has been supported by the University of Palermo, the MED-SUV project, the "Laboratoire d'Excellence VOLTAIRE" de l'Université d'Orléans, and the French agency for research (ANR project \#12-JS06-0009-01). We are grateful I. Di Carlo (ISTO, Orléans) for her assistance with the SEM and the EMP methods, E. Deloule, J. Villeneuve and A. Gurenko (CRPG, Nancy) for their support during SIMS acquisitions, A. Correale (INGV, Palermo) and A. Rosciglione to have provided some Etnean samples. We thank Rosanna Corsaro, an anonymous reviewer and Vadim Kamenetsky for their useful comments, and Nelson Eby for the careful handling of the manuscript. 


\section{References}

Aiuppa, A., Giudice, G., Gurrieri, S., Liuzzo, M., Burton, M., Caltabiano, T., McGonigle, A.J.S.,

Salerno, G., Shinohara, H., Valenza, M., 2008. Total volatile flux from Mount Etna. Geophysical Research Letters 35, L24302. https://doi.org/10.1029/2008GL035871.

Aiuppa., A., Fischer, T.P., Plank, T., Robidoux, P., Di Napoli, R., 2017. Along-arc, inter-arc and arc-to-arc variations in volcanic gas $\mathrm{CO}_{2} / \mathrm{S}_{\mathrm{T}}$ ratios reveal dual source of carbon in arc volcanism. Earth-Science Reviews 168, 24-47.

Allard, P., Behncke, B., D’Amico, S., Neri, M., Gambino, S., 2006. Mount Etna 1993-2005: Anatomy of an evolving eruptive cycle. Earth-Science Reviews 78, 85-114. https://doi.org/10.1016/j.earscirev.2006.04.002.

Aloisi, M., Cocina, O., Neri, G., Orecchio, B., Privitera, E., (2002). Seismic tomography of the crust underneath the Etna volcano, Sicily. Physics of the Earth and Planetary Interiors 134, 139155.

Andronico, D., Branca, S., Calvari, S., Burton, M., Caltabiano, T., Corsaro, R.A., Del Carlo, P., Garfi, G., Lodato, L., Miraglia, L., others, 2005. A multi-disciplinary study of the 2002-03 Etna eruption: insights into a complex plumbing system. Bulletin of Volcanology 67, 314-330. 
Armienti, P., Innocenti, F., Petrini, R., Pompilio, M., Villari, L., 1988. Sub-aphyric alkali basalt from Mt. Etna: inferences on depth and composition of the source magma. Rendiconti della Società Italiana di Mineralogia e Petrografia 43, 877-891.

Armienti P., Tonarini S., D’Orazio M., Innocenti F., 2004. Genesis and Evolution of Mt. Etna alkaline lavas: petrological and Sr-Nd-B isotope costraints. Periodico di Mineralogia 73, 29-52.

Armienti, P., Tonarini, S., Innocenti, F. and D’Orazio, M., 2007. Mount Etna pyroxene as tracer of petrogenetic processes and dynamics of the feeding system. In: Beccaluva, L., Bianchini, G. and Wilson, M. (eds) Cenozoic Volcanism in the Mediterranean Area. Geological Society of America, Special Papers 418, 265-276, doi:10.1130/2007.2418 (13).

Armienti, P., Perinelli, C., Putirka, K.D., 2012. A New Model to Estimate Deep-level Magma Ascent Rates, with Applications to Mt. Etna (Sicily, Italy). Journal of Petrology 54, 795-813. https://doi.org/10.1093/petrology/egs085.

Ballhaus, C., Berry, C. F., Green, D. H., 1991. High pressure experimental calibration of the olivine-orthopyroxene-spinel oxygen geobarometer: implications for the oxidation state of the upper mantle. Contributions to Mineralogy and Petrology 108, 82-92.

Bonaccorso, A., Bonforte, A., Calvari, S., Del Negro, C., Di Grazia, G., Ganci, G., Neri, M., Vicari, A., Boschi, E., 2011. The initial phases of the 2008-2009 Mt. Etna eruption: a multi-disciplinary 
approach for hazard assessment. Journal of Geophysical Research, Vol. 116, B03203, doi: 10.1029/2010JB007906.

Branca, S., Coltelli, M., Groppelli, G., 2011. Geological evolution of a complex basaltic stratovolcano: Mount Etna, Italy. Italian Journal of Geosciences 130, 306-317.

Bucholz, C.E., Gaetani, G.A., Behn, M.D., Shimizu, N., 2013. Post-entrapment modification of volatiles and oxygen fugacity in olivine-hosted melt inclusions. Earth Planetary Science Letters 374, 145-155. https://doi.org/10.1016/j.eps1.2013.05.033.

Calvari, S., Coltelli, M., Neri, M., Pompilio, M., Scribano, V., 1994. The 1991-1993 Etna eruption: chronology and lava. Acta Vulcanologica 4, 1-14.

Cecchetti, A., Marianelli, P., Sbrana, A., 2002. L'eruzione Di Astroni (Caldera Dei Campi Flegrei): Dati Preliminari Dallo Studio Di Inclusioni Silicatiche. Atti della Società toscana di scienze naturali. Memorie, Serie A, 108 (2002-2003) pagg. 59-63.

Chiodini, G., Caliro, S., Aiuppa, A., Avino, R., Granieri, R., Moretti, R., Parello, F., 2011. First $13 \mathrm{C} / 12 \mathrm{C}$ isotopic characterisation of volcanic plume $\mathrm{CO}_{2}$ Bullettin of Volcanology, 73:531-542 DOI 10.1007/s00445-010-0423-2. 
Clocchiatti, R., Joron, J.L., Treuil, M., 1988. The role of selective alkali contamination in the evolution of recent historical lavas of Mt. Etna. Journal of Volcanology and Geothermal Research 34, 241-249.

Clocchiatti, R., Schiano, P., Ottolini, L., Bottazzi, P., 1998. Earlier alkaline and transitional magmatic pulsation of Mt. Etna volcano. Earth and Planetary Science Letters 163, 399-407.

Collins, S.J., Pyle, D.M., Maclennan, J., 2009. Melt inclusions track pre-eruption storage and dehydration of magmas at Etna. Geology 37, 571-574. https://oi.org/10.1130/G30040A.1.

Coltelli, M., Del Carlo, P., Vezzoli, L., 1998. Discovery of a Plinian basaltic eruption of Roman age at Etna volcano, Italy. Geology 26, 1095-1098.

Coltelli, M., Del Carlo, P., Pompilio, M., Vezzoli, L., 2005. Explosive eruption of a picrite: The 3930 BP subplinian eruption of Etna volcano (Italy). Geophysical Research Letters 32, L23307. https://doi.org/10.1029/2005 GL024271.

Condomines, M., Tanguy, J.C., Michaud, V., 1995. Magma dynamics at Mt. Etna: constraints from $\mathrm{U}-\mathrm{Th}-\mathrm{Ra}-\mathrm{Pb}$ radioactive disequilibria and $\mathrm{Sr}$ isotopes in historical lavas. Earth and Planetary Science Letters 132, 25-41. 
Continisio, R., Ferrucci, F., Gaudiosi, G., Lo Bascio, D., Ventura, G., 1997. Malta Escarpment Mt. Etna: early stages of an asymmetric rifting process? Evidences from geophysical and geological data. Acta Vulcanologica 9, 45-53.

Correale, A., Paonita, A., Martelli, M., Rizzo, A., Rotolo, S.G., Corsaro, R.A., Di Renzo, V., 2014. A two-component mantle source feeding Mt. Etna magmatism: Insights from the geochemistry of primitive magmas. Lithos 184, 243-258. https://doi.org/10.1016/j.lithos.2013.10.038.

Corsaro, R.A., and Pompilio, M., 2004a. Dynamics of magmas at Mount Etna. In: Mount Etna: Volcano Laboratory. Geophysical Monograph Series 143, 91-110.

Corsaro, R.A., Pompilio, M., 2004b. Buoyancy-controlled eruption of magmas at Mt. Etna. Terra Nova 16, 16-22. https $/ / d o i . o r g / 10.1046 / j .1365-3121.2003 .00520 . x$.

Corsaro, R.A., Métrich, N., Allard, P., Andronico, D., Miraglia, L., Fourmentraux, C., 2009. The 1974 flank eruption of Mount Etna: An archetype for deep dike-fed eruptions at basaltic volcanoes and a milestone in Etna's recent history. Journal of Geophysical Research: Solid Earth 114, B07204. https://doi.org/10.1029/2008JB006013.

Corsaro, R.A., Métrich, N., 2016. Chemical heterogeneity of Mt. Etna magmas in the last 15 ka. $\begin{array}{lllll}\text { Inferences } & \text { on } \quad \text { their } & \text { mantle } & \text { sources. } & \text { Lithos }\end{array}$ https://doi.org/10.1016/j.lithos.2016.02.006. 
Coulson, I.M., Stuart, F.M., MacLean, N.J., 2011. Assessing the link between mantle source and sub-volcanic plumbing in the petrology of basalts from the 2001 and 2002/2003 eruptions of Mount Etna, Sicily: Evidence from geochemical and helium isotope data. Lithos, Secular variations in magmatism and tectonic implications Special session at the 2009 Geological Association of Canada - Mineralogical Association of Canada (GAC-MAC) meeting 123, 254-261. doi:10.1016/j.lithos.2010.11.013.

Danyushevsky, L.V., Della-Pasqua, F.N., Sokolov, S., 2000. Re-equilibration of melt inclusions trapped by magnesian olivine phenocrysts from subduction-related magmas: petrological implications. Contribution to Mineralogy and Petrology 138, 68-83. https://doi.org/10.1007/PL00007664

Danyushevsky, L.V., Sokolov, S., Falloon, T.J., 2002. Melt Inclusions in Olivine Phenocrysts: Using Diffusive Re-equilibration to Determine the Cooling History of a Crystal, with Implications for the Origin of Olivine-phyric Volcanic Rocks. Journal of Petrology 43, 1651-1671. https://doi.org/10.1093/petrology/43.9.1651

Danyushevsky, L. V., R. A. J. Leslie, A. J. Crawford, and P. Durance, 2004. Melt inclusions in primitive olivine phenocrysts: The role of localized reaction processes in the origin of anomalous compositions, Journal of Petrology, 45, 2531-2553. 
Danyushevsky, L.V., Plechov, P., 2011. Petrolog3: Integrated software for modeling crystallization

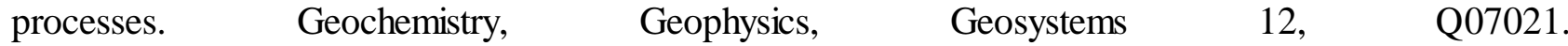
https://doi.org/10.1029/2011 GC003516

Dixon, J. E., Stolper, E., Delaney, J.R., 1988. Infrared spectroscopic measurements of $\mathrm{CO}_{2}$ and $\mathrm{H}_{2} \mathrm{O}$ in Juan de Fuca Ridge basaltic glasses. Earth and Planetary Science Letters, 90, 87-104 87.

Dixon, J. E. and Pan, V., 1995. Determination of the molar absorptivity of dissolved carbonate in basanitic glass. American Mineralogist 80, 1339-1342.

Doglioni, C., Innocenti, F., Mariotti, G., 2001. Why Mt. Etna? Terra Nova 13, 25-31. https://doi.org/10.1046/j.1365-3121.2001.00301.x.

Ferlito, C., Lanzafame, G., 2010. The role of supercritical fluids in the potassium enrichment of magmas at Mount Etna volcano (Italy). Lithos 119, 642-650.

Ferlito, C., Coltorti, M., Lanzafame, G., Giacomoni, P.P., 2014. The volatile flushing triggers eruptions at open conduit volcanoes: evidence from Mount Etna volcano (Italy). Lithos 184, 447455.

Fine G. and Stolper E., 1986. Dissolved carbon-dioxide in basaltic glasses-concentrations and speciation. Earth Planetary and Science Letters 76, 263-278. 
Finetti I.R., Lentini F., Carbone S., Del Ben A., Di Stefano A., Forlin E., Guarnieri P., Pipan M., Prizzon A., 2006. Geological outline of Sicily and lithospheric tectono-dynamics of its Tyrrhenian margin from new CROP Seismic data. In CROP Project: deep seismic exploration of the Central Mediterranean and Italy, Ed. Finetti I.R., 319-376.

Frezzotti, M.-L., 2001. Silicate-melt inclusions in magmatic rocks: applications to petrology. Lithos 55, 273-299. https//doi.org/10.1016/S0024-4937(00)00048-7.

Gaetani, G., A., and Watson, B., E., 2002. Modeling the major-element evolution of olivine-hosted melt inclusions. Chemical Geology 183, 25-41.

Gaetani, G.A., O’Leary, J.A., Shimizu, N., Bucholz, C.E., Newville, M., 2012. Rapid reequilibration of $\mathrm{H}_{2} \mathrm{O}$ and oxygen fugacity in olivine-hosted melt inclusions. Geology 40, 915918. https $/ /$ doi.org/10.1130/G32992.1.

Gennaro, E. 2017. Sulfur behavior and redox conditions in Etnean hydrous basalts inferred from melt inclusions and experimental glasses. $\mathrm{PhD}$ thesis, Università degli Studi di Palermo, Université d'Orléans.

Giacomoni, P.P., Coltorti, M., Bryce, J.G., Fahnestock, M.F., Guitreau, M., 2016. Mt. Etna plumbing system revealed by combined textural, compositional, and thermobarometric studies in 
clinopyroxenes. Contribution to Mineralogy and Petrology 171:34. DOI 10.1007/s00410-016-12477.

Ghiorso, M.S., Sack, R.O., 1995. Chemical mass transfer in magmatic processes IV. A revised and internally consistent thermodynamic model for the interpolation and extrapolation of liquid-solid equilibria in magmatic systems at elevated temperatures and pressures. Contribution to Mineralogy and Petrology 119, 197-212. https://doi.org/10.1007/BF00307281.

Gvirtzman, Z., Nur, A., 1999. The formation of Mount Etna as the consequence of slab rollback. Nature 401, 782-785. https $/ /$ doi.org/10.1038/44555.

Iacono Marziano, G., Morizet, Y., Le Trong, E., Gaillard, F., 2012. New experimental data and semi-empirical parameterization of $\mathrm{H}_{2} \mathrm{O}-\mathrm{CO}_{2}$ solubility in mafic melts. Geochimica et Cosmochima Acta 97, 1-23. https $/ /$ doi.org/10.1016/j.gca.2012.08.035.

Iacono-Marziano, G., Ferraina, C., Gaillard, F., Di Carlo, I., Arndt, N.T., 2017. Assimilation of sulfate and carbonaceous rocks: Experimental study, thermodynamic modeling and application to the Noril'sk-Talnakh region (Russia). Ore Geology Reviews, 90, 399-413.

Ihinger P. D., Hervig R. L. and McMillan P. F., 1994. Analytical methods for volatiles in glasses. Reviews in Mineralogy and Geochemistry 30,67-121. 
Innocenti, F., Rocchi, S., Trigila, R., 1999. La classificazione delle rocce vulcaniche e subvulcaniche: schema operativo per il progetto CARG. Atti della Società toscana di scienze naturali. Memorie, Serie A 106, pagg. 113-124, figg. 17, tabb. 8.

Jarosewich E., Parkes A.S., Wiggins L.B., 1979. Microprobe analyses of four natural glasses and one mineral: an interlaboratory study of precision and accuracy. Smithsonian Contributions to the Earth Science, 22:53-67.

Jochum K.P., Stoll B., Hervig K., Willbold M., Hofmann A.W., Amini M., Aarburg S., Abouchami W., Hellebrand E., Mocek B., Raczek I., Strake A., Alard O., Bouman C., Becker S., Ducking M., Bratz H., Klemd R., de Bruin D., Canil D., Cornell D., De Hoog C-J., Dalpé C., Danyushevsky L., Eisenhauer A., Gao Y., Snow J., Groschopf N., Gunther D., Latkoczy C., Guillong M., Hauri E.H., Hofer H.E., Lahaye Y., Horz K., Jacob D.E., Kasemann S.A., Kent A.J.R., Ludwig T., Zack T., Mason P.R.D., Meixner A., Rosner M., Misawa K., Nash B.P., Pfander J., Premo W.R., Sun W.D., Tiepolo M., Vannucci R., Vennemann T., Wayne D., Woodhead J.D., 2006. MPI-DING reference glasses for in situ microanalysis: New reference values for element concentrations and isotope ratios. Geochemistry, Geophysics, Geosystems 7, Q02008, doi:10.1029/2005GC001060.

Joron, J.L., Treuil, M., 1984. Etude geochimique et pétrogenèse des laves de l'Etna. Bulletin of Volcanology 47, 1125-1144.

Jugo, P.J., 2009. Sulfur content at sulfide saturation in oxidized magmas. Geology 37, 415-418. https://doi.org/10.1130/G25527A.1. 
Kahl, M., Chakraborty, S., Costa, F., Pompilio, M., 2011. Dynamic plumbing system beneath volcanoes revealed by kinetic modeling, and the connection to monitoring data: An example from Mt. Etna. Earth Planetary Science Letters 308, 11-22. https://doi.org/10.1016/j.eps1.2011.05.008.

Kahl, M., Chakraborty, S., Pompilio, M., Costa, F., 2015. Constraints on the Nature and Evolution of the Magma Plumbing System of Mt. Etna Volcano (1991-2008) from a Combined Thermodynamic and Kinetic Modelling of the Compositional Record of Minerals. Journal of Petrology 56, 2025-2068. https://doi.org/10.1093/petrology/egv063.

Kamenetsky, V., Clocchiatti, R., 1996. Primitive magmatism of Mt. Etna: insights from mineralogy and melt inclusions. Earth Planetary Science Letters 142, 553-572. https://doi.org/10.1016/0012$821 X(96) 00115-X$

Kamenetsky, V.S., Pompilio, M., Métrich, N., Sobolev, A.V., Kuzmin, D.V., Thomas, R., 2007. Arrival of extremely volatile-rich high-Mg magmas changes explosivity of Mount Etna. Geology 35, 255-258. https//doi.org/10.1130/G23163A.1

Lanzo, G., Di Carlo, I., Pichavant, M., Rotolo, S. G., Scaillet, B., 2016. Origin of primitive ultracalcic arc melts at crustal conditions - Experimental evidence on the La Sommata basalt, Vulcano, Aeolian Islands. Journal of Volcanology and Geothermal Research, Elsevier, 321, pp.85-101. 
Le Gall, N., Pichavant, M., 2016. Experimental simulation of bubble nucleation and magma ascent in basaltic systems: Implications for Stromboli volcano. American Mineralogist 101, 1967-1985. https://doi.org/10.2138/am-2016-5639.

Lentini, F.,1982. The geology of Mt. Etna basement. Memorie della Società Geologica Italiana, 23, $7-25$.

Lesne, P., Bruno Scaillet, Michel Pichavant, Jean-Michel Bény, 2011. The carbon dioxide solubility in alkali basalts: an experimental study. Contribution to Mineralogy and Petrology 162, 153-168. https://doi.org/10.1007/s00410-010-0585-0.

Liotta, M., Rizzo, A., Paonita, A., Caracausi, A., Martelli, M., 2012. Sulfur isotopic compositions of fumarolic and plume gases at Mount Etna (Italy) and inferences on their magmatic source. Geochemistry, Geophysics, Geosystems 13, Q05015. https://doi.org/10.1029/2012GC004118

Lloyd, A., S., Plank, T., Ruprecht, P., Hauri, E. H., Rose, W., 2013. Volatile loss from melt inclusions in pyroclasts of differing sizes. Contribution to Mineralogy and Petrology 165, 129-153. DOI 10.1007/s00410-012-0800-2.

Metrich, N., Clocchiatti, R., 1989. Melt inclusion investigation of the volatile behaviour in historic alkali basaltic magmas of Etna. Bulletin of Volcanology 51, 185-198. https://doi.org/10.1007/BF01067955. 
Metrich, N., Bertagnini, A., Landi, P., Rosi, M., 2001. Crystallization driven by decompression and water loss at Stromboli volcano (Aeolian Islands, Italy), Journal of Petrology 42, 1471- 1490.

Metrich, N., Allard, P., Spilliaert, N., Andronico, D., Burton, M., 2004. 2001 flank eruption of the alkali- and volatile-rich primitive basalt responsible for Mount Etna's evolution in the last three decades. Earth Planetary Science Letters 228, 1-17. https://doi.org/10.1016/j.eps1.2004.09.036.

Michaud, V., 1995. Crustal xenoliths in recent hawaiites from Mount Etna, Italy: evidence for alkali exchanges during magma-wall rock interaction. Chemical Geology 122, 21-42.

Mollo, S., Giacomoni, P.P., Coltorti, M., Ferlito, C., Iezzi, G., Scarlato, P., 2015. Reconstruction of magmatic variables governing recent Etnean eruptions: Constraints from mineral chemistry and $\mathrm{P}-$ $\mathrm{T}-f \mathrm{O}_{2}-\mathrm{H}_{2} \mathrm{O}$ modeling. Lithos $212-215$, pp. 311-320.

Moore, L.R., Gazel, E., Tuohy, R., Lloyd, A.L., Esposito, R., Steele-MacInnis, M., Hauri, E.H., Wallace, P.J., Plank, T., and Bodnar, R.J., 2015. Bubbles matter: An assessment of the contribution of vapor bubbles to melt inclusion volatile budgets. SPECIAL COLLECTION: glasses, melts, and fluids, as tools for understanding volcanic processes and hazards. American Mineralogist, Volume 100, pages 806-823, DOI: http://dx.doi.org/10.2138/am-2015-5036. 
Moretti, R., Métrich, N., Arienzo, I., Di Renzo, V., Aiuppa, A., Allard, P., 2018. Degassing vs. eruptive styles at Mt. Etna volcano (Sicily, Italy). Part I: Volatile stocking, gas fluxing, and the shift from low-energy to highly explosive basaltic eruptions. Chemical Geology 482, 1-17.

Norrish, K., Hutton, J.T., 1969. An accurate X-ray spectrographic method for the analysis of a wide range of geological samples. Geochimica et Cosmochimica Acta 33, 431-453. https://doi.org/10.1016/0016-7037(69)90126-4.

Paonita, A., Caracausi, A., Iacono-Marziano, G., Martell, M., Rizzo, A., 2012. Geochemical evidence for mixing between fluids exsolved at different depths in the magmatic system of Mt Etna (Italy). Geochimica et Cosmochimica Acta 84, 380-394. https://doi.org/10.1016/j.gca.2012.01.028.

Pichavant, M., Martel, C., Bourdier, J.L., and Scaillet, B., 2002. Physical conditions, structure, and dynamicsof a zoned magma chamber: Mount Pele'e (Martinique, Lesser Antilles Arc). Journal of Geophysical Research, Vol. 107, No. B5, 2093, 10.1029/2001jb000315.

Pichavant, M., Di Carlo, I., Le Gac, Y., Rotolo, S. G., Scaillet, B., 2009. Experimental Constraints on the Deep Magma Feeding System at Stromboli Volcano, Italy. Journal of Petrology, Volume 50, Number 4 Pages 601-624 2009 Doi:10.1093/Petrology/Egp014.

Pichavant, M., Di Carlo, I., Rotolo, S., Scaillet, B., Burgisser, A., Le Gall, N., Martel, C., 2013. Generation of $\mathrm{CO}_{2}$-rich melts during basalt magma ascent and degassing. Contribution to Mineralogy and Petrology 166:545-561 DOI 10.1007/s00410-013-0890-5. 
Pompilio M, Coltelli M, Del Carlo P, Vezzoli L, 1995. How do basaltic magmas, feeding explosive eruptions, rise and differentiate at Mt. Etna? Periodico di Mineralogia, 64 (1-2), pp. 253-254.

Richet, P., Whittington, A., Holtz, F., Behrens, H., Ohlhorst, S., Wilke, M., 2000. Water and the density of silicate glasses. Contributions to Mineralogy and Petrology 138(4): 337-347.

Portnyagin, M.V., Almeev, R.R., Matveev, S., Holtz, F., 2008. Experimental evidence for rapid water exchange between melt inclusions in olivine and host magma. Earth and Planetary Science Letters 272, 541-552.

Rizzo, A.L., Caracausi, A., Liotta, M., Paonita, A., Barnes, J.D., Corsaro, R.A., Martelli, M., 2013. Chlorine isotope composition of volcanic gases and rocks at Mount Etna (Italy) and inferences on the local mantle source. Earth Planetary Science Letters 371-372, 134-142. https://oi.org/10.1016/j.eps1.2013.04.004

Robidoux, P., Aiuppa, A., Rotolo, S.G., Rizzo, A.L., Hauri, E.H., Frezzotti, M.L., 2017. Volatile contents of mafic-to-intermediate magmas at San Cristóbal volcano in Nicaragua. Lithos 272-273, pp. $147-163$.

Rose-Koga, E.F., Koga, K.T., Schiano, P., Le Voyer, M., Shimizu, N., Whitehouse, M.J., Clocchiatti, R., 2012. Mantle source heterogeneity for South Tyrrhenian magmas revealed by $\mathrm{Pb}$ 
isotopes and halogen contents of olivine-hosted melt inclusions. Chemical Geology 334, 266-279. https://doi.org/10.1016/j.chemgeo.2012.10.033.

Schiano, P., Clocchiatti, R., 1994. Worldwide occurrence of silica-rich melts in sub-continental and sub-oceanic mantle minerals. Nature 368, 621-624. https//doi.org/10.1038/368621a0.

Schiano, P., Crocchiati, R., Ottolini, L., Busà, T., 2001. Transition of Mount Etna lavas from a mantle-plume to an island-arc magmatic source. Nature 412, 900-904.

Schiavi, F., Rosciglione, A., Kitagawa, H., Kobayashi, K., Nakamura, E., Nuccio, P.M., Ottolini, L., Paonita, A., Vannucci, R., 2015. Geochemical heterogeneities in magma beneath Mount Etna recorded by 2001-2006 melt inclusions. Geochemistry Geophysics Geosystems 16, 2109-2126. https://doi.org/10.1002/2015GC005786.

Schiavi, F., Provost, A., Schiano, P., Cluzel, N., 2016. P-V-T-X evolution of olivine-hosted melt inclusions during high-temperature homogenization treatment. Geochim. Cosmochim. Acta 172, 121. https://doi.org/10.1016/j.gca.2015.09.025.

Shishkina, T.A., Botcharnikov, R.E., Holtz, F., Almeev, R.R., Portnyagin, M.V., 2010. Solubility of $\mathrm{H}_{2} \mathrm{O}$ - and $\mathrm{CO}_{2}$-bearing fluids in tholeiitic basalts at pressures up to 500MPa. Chemical Geology 277, 115-125. 
Smith, P.M., Asimow, P.D., 2005. Adiabat_1ph: A new public front-end to the MELTS, pMELTS, and pHMELTS models. Geochemistry Geophysics Geosystems 6, Q02004. https://doi.org/10.1029/2004GC000816.

Sobolev, A.V., Kamenetsky, V.S., Metrich, N., Clocchiatti, R., Kononkova, N.N., Devirts, A.L., 1991. Volatile regime and crystallization conditions in Etna hawaiite lavas. Geochemistry International 28, 53-65.

Sobolev, A.V., Danyushevsky, L.V., 1994. Petrology and geochemistry of bonitites from the north termination of the Tonga Trench: constraints on the generation conditions of primary high-Ca boninite magmas. Journal of Petrology 35, 1183-1211.

Sobolev, A.V., 1996. Melt inclusions in minerals as a source of principle petrological information. Petrology 4, 228-239.

Spilliaert, N., Allard, P., Métrich, N., Sobolev, A.V., 2006a. Melt inclusion record of the conditions of ascent, degassing, and extrusion of volatile-rich alkali basalt during the powerful 2002 flank eruption of Mount Etna (Italy). Journal of Geophysical Research: Solid Earth 111, B04203. https://doi.org/10.1029/2005JB003934.

Spilliaert, N., Metrich, N. and Allard, P., 2006b. S-Cl-F degassing pattern of water-rich alkali basalt: modelling and relationship with eruption styles on Mount Etna volcano. Earth and Planetary Science Letters 248, 772-786. 
Stolper, E., 1982. Water in silicate glasses: an infrared spectroscopic study. Contributions to Mineralogy and Petrology 81, 1-17.

Tanguy, J.C., 1978. Tholeitic basalt magmatism of Mount Etna and its relations with the alkaline series. Contributions to Mineralogy and Petrology 66, 51-67.

Tanguy, J.-C., Condomines, M., Kieffer, G., 1997. Evolution of the Mount Etna magma: Constraints on the present feeding system and eruptive mechanism. Journal of Volcanology and Geothermal Research 75, 221-250. https://doi.org/10.1016/S0377-0273(96)00065-0.

Tonarini, S., Armenti, P., D'Orazio, M., Innocenti, F., Pompilio, M., Petrini, R., 1995. Geochemical and isotopic monitoring of Mt. Etna 1989-1993 eruptive activity: bearing on the shallow feeding system. Journal of Volcanology and Geothermal Research 64, 95-115.

Tonarini, S., Armienti, P., D'Orazio, M., Innocenti, F., 2001. Subduction-like fluids in the genesis of the Mt. Etna magmas: evidence from boron isotopes and fluid mobile elements. Earth and Planetary Science Letters 5989, 1-13.

Viccaro, M., Nicotra, E., Millar, I.L., Cristofolini, R., 2011. The magma source at Mount Etna volcano: Perspectives from the Hf isotope composition of historic and recent lavas. Chemical Geology 281, 343-351. 
Von Aulock, F.W., Kennedy, B.M., Schipper, C.I., Castro, J.M., Martin, D.E., Oze, C., Watkins, J.M., Wallace, P.J., Puskar, L., Bégué, F., Nichols, A.R.L., Tuffen, H., 2014. Advances in Fourier transform infrared spectroscopy of natural glasses: From sample preparation to data analysis. Lithos 206-207, 52-64.

Wallace, P.J., Kamenetsky, V.D., Cervantes, P., 2015. Melt inclusion $\mathrm{CO}_{2}$ contents, pressures of olivine crystallization, and the problem of shrinkage bubbles. American Mineralogist, Volume 100, pages $787-794.10 .2138 / a m-2015-5029$.

Witter, J.B. Kress, V. C., and Newhall, C. G., 2005. Volcán Popocatépetl,, Mexico. Petrology, Magma Mixing, and Immediate Sources of Volatiles for the 1994 Present Eruption. Journal of Petrology, 11, 2337-2366. 


\section{Figures captions}

Fig. 1 - a) Etna map (modified form Coulson et al., 2011), with the small inset illustrating the geodynamic contest of Etnean area (from Ferlito et al., 2014) and b) DEM (Digital Elevation Model) detail of the summit area, showing the sampling sites.

Fig. $2-\mathrm{CaO} / \mathrm{Al}_{2} \mathrm{O}_{3}$ versus $\mathrm{MgO}$ contents of whole rock analyses (wr, more evident in the small picture), PEC-corrected melt inclusions (MI), together with literature MI data (Collins et al., 2009; Corsaro and Métrich, 2016; Kamenetsky and Clocchiatti, 1996; Kamenetsky et al., 2007; Métrich et al., 2004; Moretti et al., 2018; Schiavi et al, 2015; Spilliaert et al., 2006a).

Fig. $3-\mathrm{K}_{2} \mathrm{O} / \mathrm{Na}_{2} \mathrm{O}$ versus $\mathrm{K}_{2} \mathrm{O}$ plot, showing the distribution of the studied Etnean glass inclusions (MI, corrected for post-entrapment crystallization) and whole rock analyses (wr), straddling the sodic/potassic affinity limit (after Innocenti et al, 1999), except the sub-alkaline FS products (also improperly reported).

Fig. 4 - BSE images of: a) skeletal clinopyroxene (cpx) and dendritic Ti-magnetite (Ti-mg) microlites in the groundmass, b) a reversely zoned olivine phenocrysts (core $=\mathrm{Fo}_{75}, \quad$ rim $=\mathrm{Fo}_{85}$ ), hosting melt inclusions and Fe-Ti oxide minerals, and c) a melt inclusion containing $\mathrm{Cr}$-spinel at the olivine rim, a bubble and few daughter crystals of Monte Spagnolo lava. d) An olivine phenocryst (Fo91) in FS juvenile tephra, hosting Cr-spinel and a melt inclusion; (e) a typical rounded melt inclusion with scalloped edges and a spherical vapor bubble, in FS. f) Olivine phenocryst in 2002/2003 scoria, entrapping a melt inclusion and Fe-Ti-oxides; g) transmitted light optical image 
of a spherical double-polished melt inclusion from 2002/2003 South eruption. h) Transmitted light image of an olivine hosting elongated melt inclusions and a glass embayment, and surrounded by matrix glass from 2006 eruption; i) BSE image of a 2008/2009 olivine hosted MI with a sulfide globule and a vapor bubble associated to an oxide. 1) $\mathrm{Cu}-\mathrm{Fe}$ sulfide and apatite microlites in the microcrystalline groundmass, and $\mathrm{m}$ ) olivine hosted melt inclusion with irregular shape and with $\mathrm{Cu}$-sulfide and Ti-magnetite phases in 2013 lava, taken by BSE technique.

Fig. 5 - Major element composition of the studied melt inclusions (MIs), using $\mathrm{K}_{2} \mathrm{O}$ as a differentiation index. All MIs data are corrected for post-entrapment crystallization (PEC) and normalized to $100 \%$.

Colored curves describe the evolution of the major elements in Etnean magma calculated by MELTS code (Ghiorso and Sack, 1995; Smith and Asimow, 2005). MELTS simulations, in the T-P range $1068-1300{ }^{\circ} \mathrm{C}$ and $0.1-500 \mathrm{MPa}$, are obtained for two different initial redox conditions $\left(\mathrm{NNO}+1<\mathrm{fO}_{2}<\mathrm{NNO}+2\right)$ and with an initial $\mathrm{H}_{2} \mathrm{O}$ contents of 5 wt.\% (see text and Table SI4 for details). Yellow curves describe the deep evolution of a primitive FS melt with a $\mathrm{dP} / \mathrm{dT}=1 \mathrm{MPa}{ }^{\circ} \mathrm{C}^{-}$ 1, while the red curves delineate the MELTS model with a $\mathrm{dP} / \mathrm{dT}=20 \mathrm{MPa}{ }^{\circ} \mathrm{C}^{-1}$. Green curves indicate $\mathrm{dP} / \mathrm{dT}=5 \mathrm{MPa}{ }^{\circ} \mathrm{C}^{-1}$ while light blue curves $\mathrm{dP} / \mathrm{dT}=3 \mathrm{MPa}{ }^{\circ} \mathrm{C}^{-1}$. The simulations starting from a $\mathrm{fO}_{2}$ of $\mathrm{NNO}+2$ are described by continues curves, while those from $\mathrm{NNO}+1$ with dashed curves.

Fig. $6-\mathrm{CO}_{2}$ and $\mathrm{H}_{2} \mathrm{O}$ contents of investigated melt inclusions (estimated by SIMS and FTIR). Isobars curves are calculated at $1200{ }^{\circ} \mathrm{C}$ using the model of Iacono-Marziano et al. (2012), and an average composition of the studied melt inclusions. The depths ("below crater levels") are calculated from the density of the sedimentary basement of Mt. Etna (Corsaro and Pompilio, 2004b). For comparison, data from previous studies are also reported (Collins et al., 2009; 
Kamenetsky et al., 2007; Metrich et al., 2004; Spilliaert et al., 2006a). The grey area is obtained simulating the degassing of the two groups of $\mathrm{FS}$ inclusions having the highest $\mathrm{H}_{2} \mathrm{O}$ and $\mathrm{CO}_{2}$ contents, using closed system condition and different initial excess of fluid phase (between 0 and 20 \%). The violet area is obtained simulating the degassing of 2002/2003 MIs with $\mathrm{H}_{2} \mathrm{O}$ and $\mathrm{CO}_{2}$ contents of $2.3 \mathrm{wt} \%$ and $2220 \mathrm{ppm}$, respectively. The error bars represent the highest standard deviations obtained for the volatile-richest inclusions.

Fig. 7 - a) $\mathrm{S}$ content in Etnean melt inclusions as a function of $\mathrm{K}_{2} \mathrm{O}$ content (considered as a differentiation index). In the investigated samples, S decrease from the Mt. Spagnolo MIs (4238 ppm) toward the evolved and degassed $\mathrm{MIs}$, following the increase of $\mathrm{K}_{2} \mathrm{O}$ in the melt. No systematic relation is observed between $\mathrm{S}$ and $\mathrm{H}_{2} \mathrm{O}$ or $\mathrm{CO}_{2}$ contents (b and c, respectively). Error bars for $\mathrm{S}, \mathrm{H}_{2} \mathrm{O}$ and $\mathrm{CO}_{2}$ contents are reported in the smaller pictures (b-c).

Fig. $8-\mathrm{CaO} / \mathrm{Al}_{2} \mathrm{O}_{3}$ versus $\mathrm{K}_{2} \mathrm{O}$ plot for Etnean melt inclusions (this study and from literature, symbols as in Fig. 2). The MELTS simulations describing the melt differentiation of $\mathrm{H}_{2} \mathrm{O}$-rich FS magma (5wt.\% $\mathrm{H}_{2} \mathrm{O}$ ) are also shown. (For details about conditions models and color curves, see text, Table SI4 and caption of Fig. 5). All resulting liquid lines of descent are generally in almost complete overlap.

Fig. $9-\mathrm{H}_{2} \mathrm{O}$ versus $\mathrm{K}_{2} \mathrm{O}$ contents of the studied melt inclusions. Literature data are also presented for FS and 2001-2007 eruptions (Collins et al., 2009; Kamenetsky et al., 2007; Metrich et al., 2004; Schiavi et al., 2015; Spilliaert et al., 2006).

Only the type II MELTS models are presented (starting from T-P of $1200{ }^{\circ} \mathrm{C}-400 \mathrm{MPa}$ ), describing $\mathrm{H}_{2} \mathrm{O}$ and $\mathrm{K}_{2} \mathrm{O}$ evolution of a primitive $\mathrm{FS}$ melt with 5 wt. $\% \mathrm{H}_{2} \mathrm{O}$ and two different initial $f \mathrm{O}_{2}$ 
conditions (NNO+1: dashed curves, NNO+2: solid curves). For details, see text and table SI4. The red curves describe a rapid decompression with a $\mathrm{dP} / \mathrm{dT}$ of $20 \mathrm{MPa}{ }^{\circ} \mathrm{C}^{-1}$ while the green and blue curves melt differentiation with a $\mathrm{dP} / \mathrm{dT}$ of 5 and $3 \mathrm{MPa}{ }^{\circ} \mathrm{C}^{-1}$ respectively.

Fig. $10-\mathrm{FeO}_{\text {tot }} / \mathrm{MgO}$ vs. $\mathrm{K}_{2} \mathrm{O}$ contents measured in Etnean melt inclusions (this study, Collins et al., 2009; Corsaro and Métrich, 2016; Kamenetsky and Clocchiatti, 1996; Kamenetsky et al., 2007; Metrich et al., 2004; Moretti et al., 2018; Schiavi et al, 2015; Spilliaert et al., 2006) and the differentiation paths calculated by MELTS (see text and Table SI4, caption of Fig. 5 for details). All data are normalized to $100 \%$ anhydrous. For the MIs symbols see the caption of Figs. 2 and 5. For a clearer understanding, data literature symbols were replaced, in some cases, by colored delimitated area. The black curve illustrates a MELTS test at very high initial $f_{\mathrm{O}_{2}}(>\mathrm{NNO}+3)$, in order to reproduce early spinel crystallization to imitate MIs of Mt. Spagnolo, Mt. Maletto and Frumento delle Concazze (see text for explanation). Some of MELTS models (with dP/dT of 20 and $5 \mathrm{MPa}$ ${ }^{\circ} \mathrm{C}^{-1}$ ) show the increase of $\mathrm{FeO}_{\text {tot }} / \mathrm{MgO}$ during fractional crystallization, similarly to that described by the evolution from FS + Mt. Spagnolo toward 2002-2013 magmas, suggesting variations in redox condition during melt evolution. Among those MIs, FS, Mt Spagnolo and 2013 are indeed characterized by a constant $\mathrm{FeO}_{\text {tot }} / \mathrm{MgO}$ ratio during evolution, ascribed to intense spinel crystallization at constant $\mathrm{fO}_{2}$ conditions (very high for FS and Mt. Spagnolo, more reduced for 2013 magma, crystallizing magnetite).

Fig. 11 - Pressure-related evolution of $\mathrm{S} \mathrm{(a)} \mathrm{and} \mathrm{Cl}$ (b) in melt inclusions from the studied eruptions. Entrapment pressures are inferred from the dissolved $\mathrm{H}_{2} \mathrm{O}$ and $\mathrm{CO}_{2}$ contents using the model of Iacono-Marziano et al. (2012). Data for 2002/2003 South eruptions of Spilliaert et al. (2006a) are also reported. 


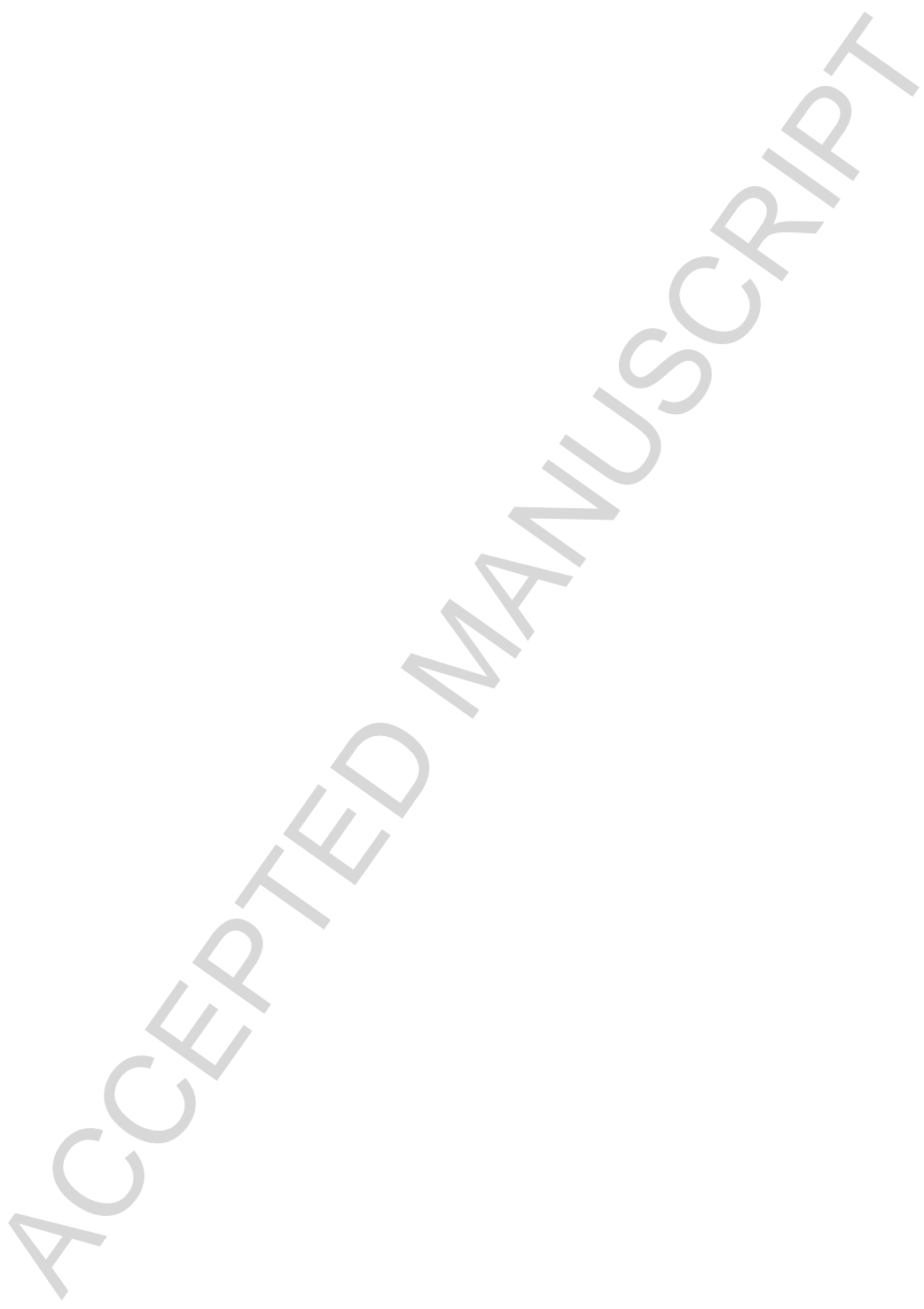


Table 1 - Whole rock compositions

\begin{tabular}{|c|c|c|c|c|c|c|}
\hline & $\begin{array}{l}\text { Mt. Spagnolo } \\
\text { lava }\end{array}$ & $\begin{array}{c}\text { FS } \\
\text { scoria }\end{array}$ & $\begin{array}{c}\text { 2002/2003 South } \\
\text { scoria }\end{array}$ & $\begin{array}{l}2006 \\
\text { scoria }\end{array}$ & $\begin{array}{c}\text { 2008/2009 } \\
\text { Bomb }\end{array}$ & $\begin{array}{l}2013 \\
\text { lava }\end{array}$ \\
\hline $\mathrm{SiO}_{2}$ & 48.37 & 46.46 & 46.93 & 48.02 & 47.50 & 48.29 \\
\hline $\mathrm{TiO}_{2}$ & 1.54 & 0.84 & 1.86 & 1.75 & 1.70 & 1.75 \\
\hline $\mathrm{Al}_{2} \mathrm{O}_{3}$ & 15.09 & 9.35 & 16.11 & 17.25 & 17.30 & 17.62 \\
\hline $\mathrm{Fe}_{2} \mathrm{O}_{3}$ & 10.42 & 10.29 & 12.20 & 11.18 & 10.80 & 11.02 \\
\hline $\mathrm{MnO}$ & 0.17 & 0.17 & 0.20 & 0.19 & 0.18 & 0.19 \\
\hline $\mathrm{MgO}$ & 7.31 & 17.90 & 6.12 & 4.96 & 4.90 & 4.69 \\
\hline $\mathrm{CaO}$ & 11.69 & 11.46 & 11.58 & 10.10 & 10.00 & 9.88 \\
\hline $\mathrm{Na}_{2} \mathrm{O}$ & 3.45 & 1.25 & 2.98 & 3.7 & 3.80 & 3.74 \\
\hline $\mathrm{K}_{2} \mathrm{O}$ & 1.40 & 0.59 & 1.90 & 2.18 & 2.10 & 2.22 \\
\hline $\mathrm{P}_{2} \mathrm{O}_{5}$ & 0.63 & 0.22 & 0.52 & 0.62 & 0.60 & 0.61 \\
\hline $\mathrm{Cr}_{2} \mathrm{O}_{3}$ & 0.04 & 0.19 & 0.02 & b.d.l. & b.d.l. & 0.03 \\
\hline LOI & 0.06 & 1.86 & -0.37 & -0.29 & 0.24 & -0.43 \\
\hline Total & 100.2 & 100.6 & 100.0 & 99.7 & 99.1 & 99.6 \\
\hline $\mathrm{Cl}$ & 0.16 & 0.08 & 0.12 & 0.11 & 0.077 & 0.12 \\
\hline S & 0.01 & b.d.l. & 0.01 & 0.01 & 0.01 & b.d.l. \\
\hline Mg\# & 58.16 & 77.51 & 49.85 & 46.78 & 47.34 & 45.75 \\
\hline $\mathrm{CaO} / \mathrm{Al}_{2} \mathrm{O}_{3}$ & 0.77 & 12 & 0.72 & 0.59 & 0.58 & 0.56 \\
\hline
\end{tabular}

Major elements, chlorine, and sulfur contents of the studied rocks (expressed in wt.\%).

$\mathrm{LOI}=$ loss on ignition; $\mathrm{Mg} \#=100 \mathrm{x} \mathrm{Mg} /\left(\mathrm{Mg}+\mathrm{Fe}_{\mathrm{tot}}\right)$; b.d.l. = below detection limit. 


\section{Highlights}

Major elements and volatiles in Etnean melt inclusions of the last $15 \mathrm{ky}$ are variable.

The highest volatile contents are found in the deepest and more primitive melt inclusions.

Melt inclusions describe clear trends of progressive degassing and melt evolution. 

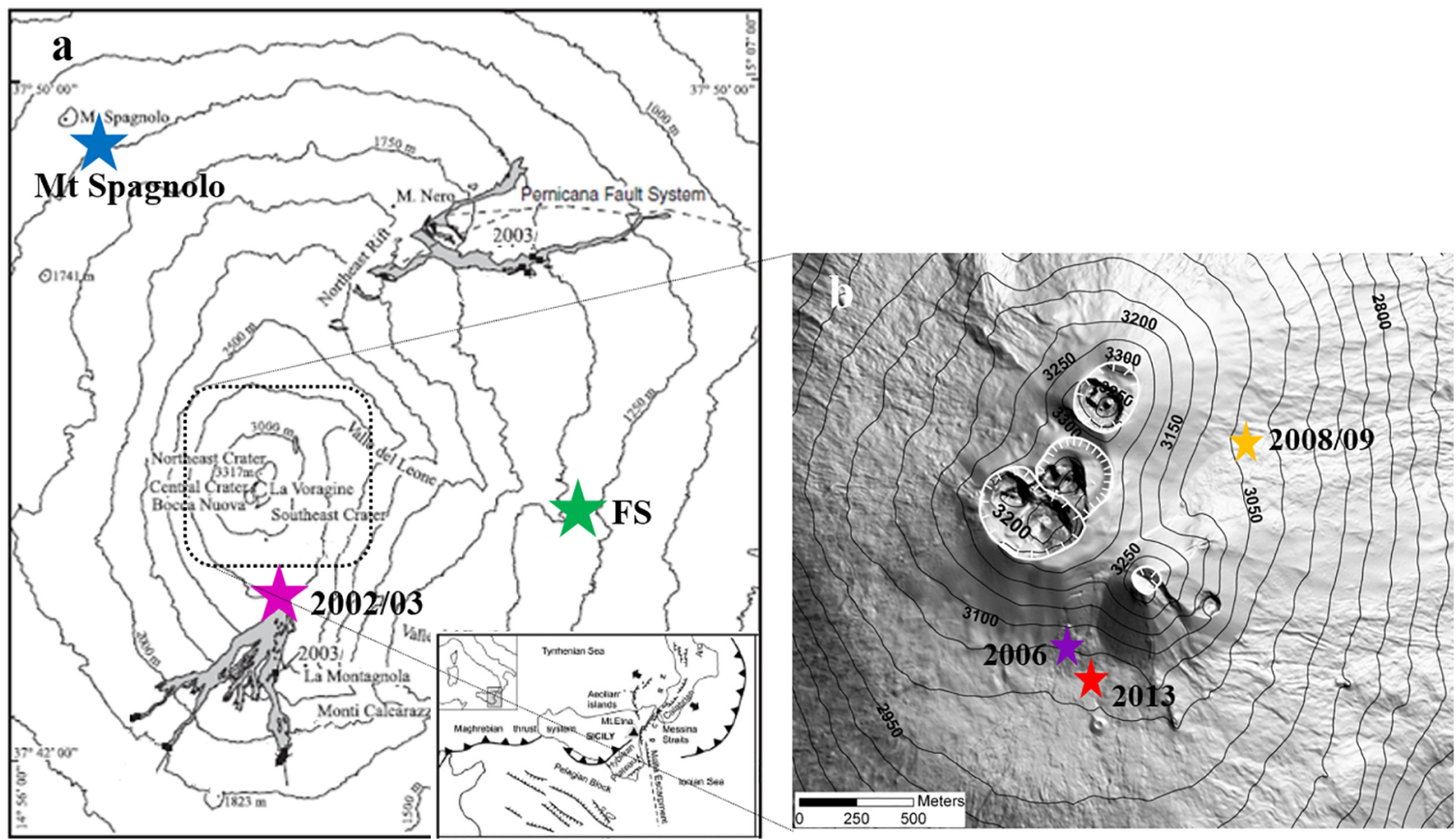

Figure 1 


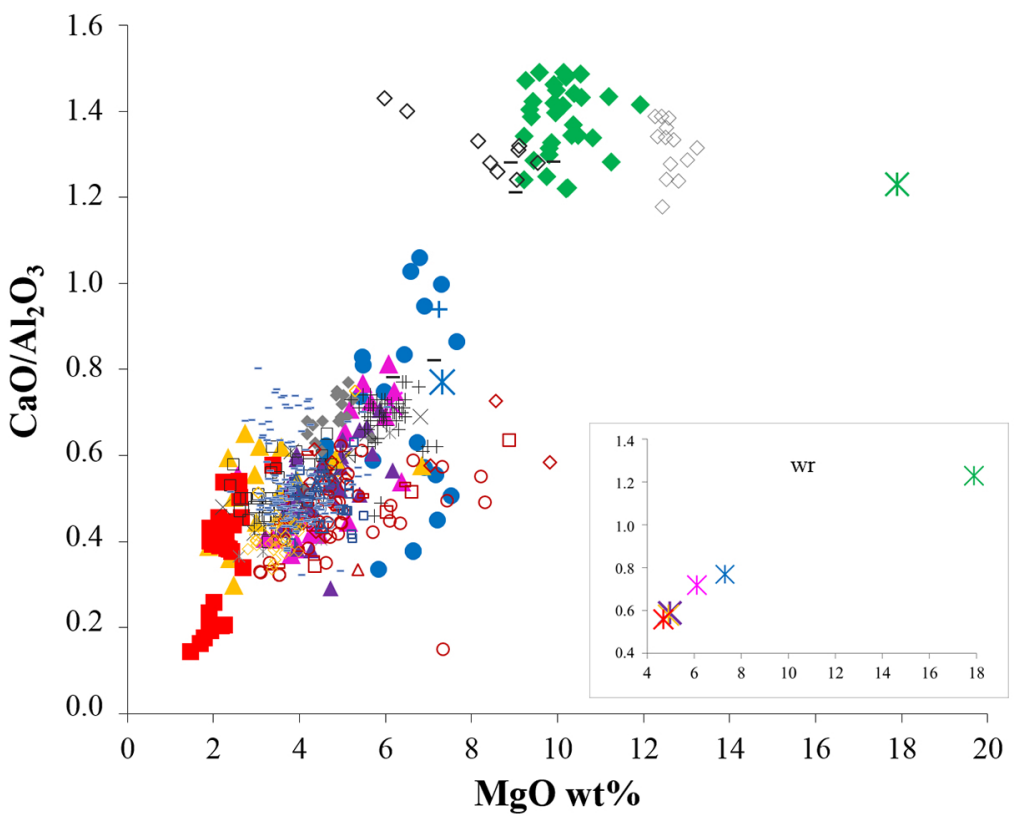

\begin{tabular}{|c|}
\hline *Mt Spagnolo (wr) \\
\hline *FS (wr) \\
\hline *2002/3 South (wr) \\
\hline *2006 (wr) \\
\hline \%2008/9 (wr) \\
\hline \#2013 (wr) \\
\hline - Mt Spagnolo (MI) \\
\hline • FS (MI) \\
\hline$\Delta 2002 / 3$ South $(\mathrm{MI})$ \\
\hline$\Delta 2006$ (MI) \\
\hline$\triangle 2008 / 9$ (MI) \\
\hline$=2013(\mathrm{MI})$ \\
\hline + Mt Spagnolo (Kamenetsky \& Clocchiatti, 1996) \\
\hline - Mt Maletto (Kamenetsky \& Clocchiatti, 1996) \\
\hline$\diamond$ FS (Kamenetsky et al., 2007) \\
\hline ১FS (Corsaro \& Métrich, 2016) \\
\hline - FdC (Corsaro \& Métrich, 2016) \\
\hline$\square$ 1995-1999 (Corsaro \& Métrich, 2016) \\
\hline ×2001 (Métrich et al., 2004) \\
\hline +2002/3 (Spilliaert et al., 2006a) \\
\hline$\square 2001$ (Collins et al., 2009) \\
\hline$\Delta 2002$ (Collins et al., 2009) \\
\hline$\diamond 2004$ (Collins et al., 2009) \\
\hline O2006 (Collins et al., 2009) \\
\hline - 2007 (Collins et al., 2009) \\
\hline 口2001(Schiavi et al., 2015) \\
\hline$\Delta 2002$ (Schiavi et al., 2015) \\
\hline 2006 (Schiavi et al., 2015) \\
\hline 122 BC (Moretti et al., 2018) \\
\hline -1997-99 (Moretti et al.. 2018) \\
\hline
\end{tabular}

Figure 2 


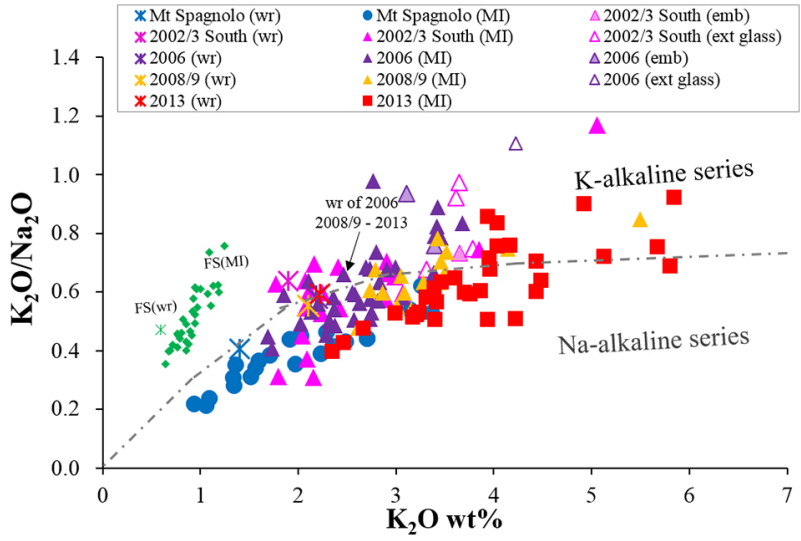

Figure 3 

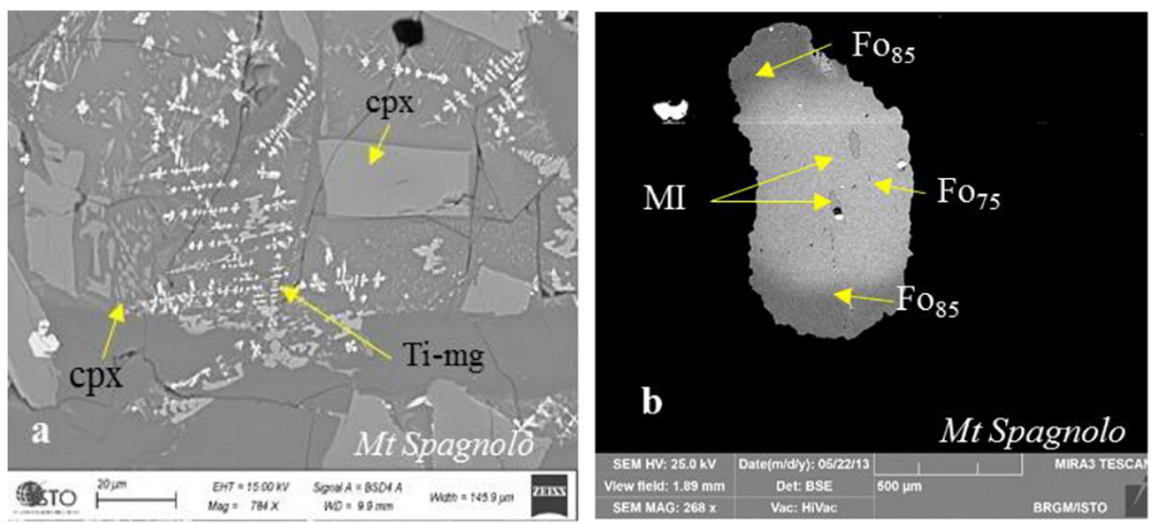

Cr-spinel
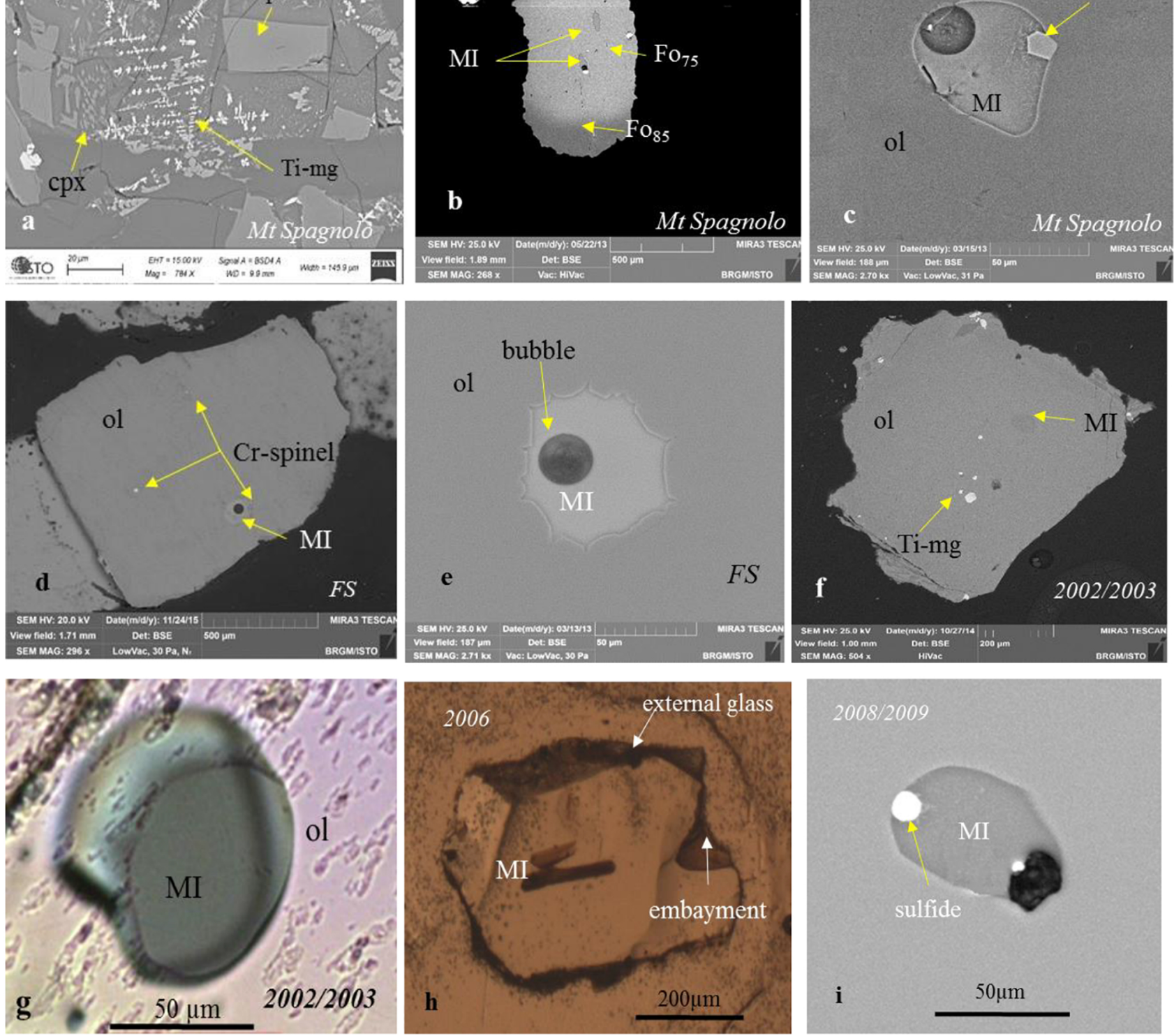

$2008 / 2009$ 

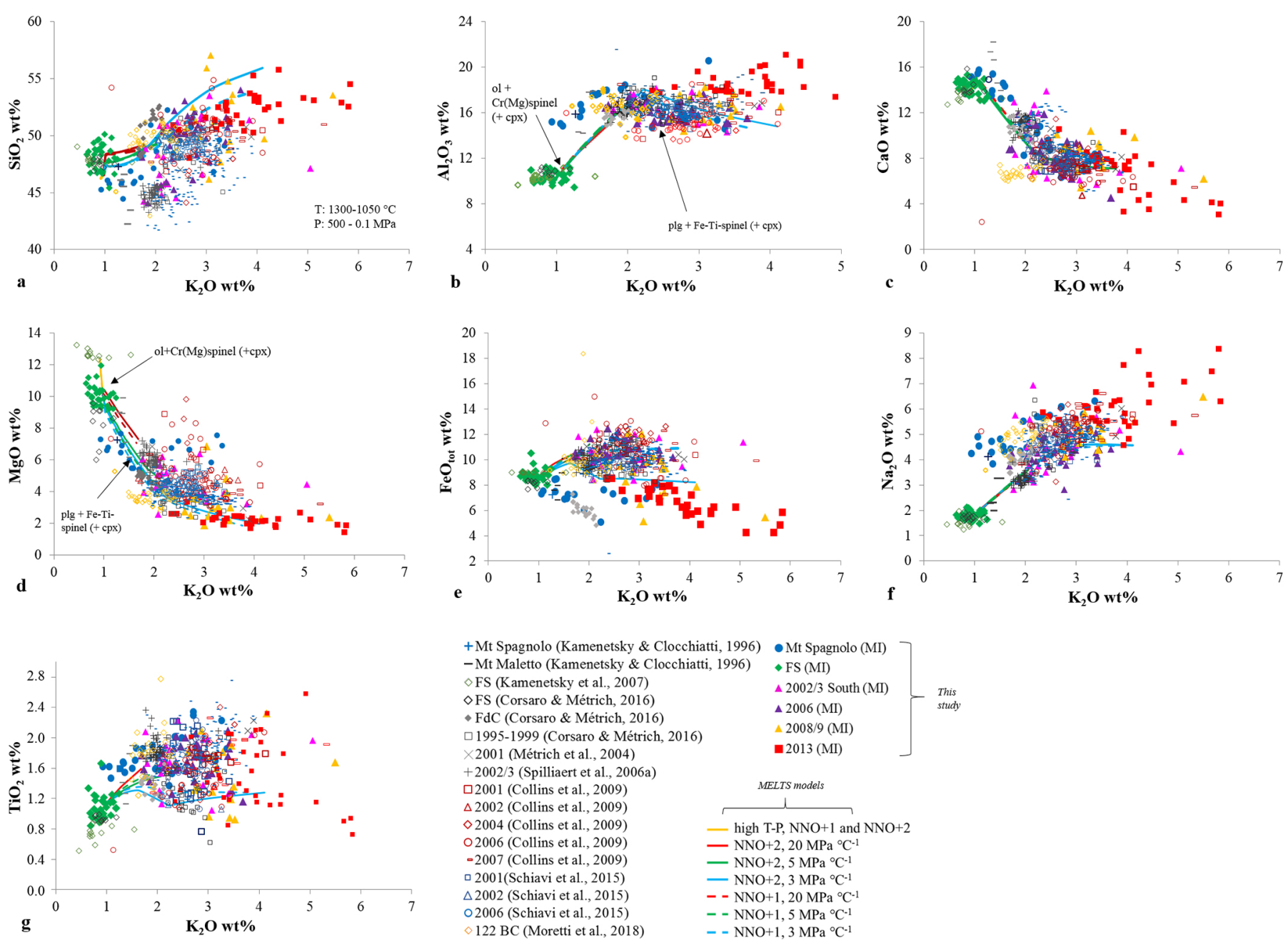

+Mt Spagnolo (Kamenetsky \& Clocchiatti, 1996) $\bullet$ Mt Spagnolo (MI) -Mt Maletto (Kamenetsky \& Clocchiatti, 1996) • FS (MI)

$\diamond$ FS (Kamenetsky et al., 2007)

$\diamond$ FS (Corsaro \& Métrich, 2016)

- FdC (Corsaro \& Métrich, 2016)

- 1995-1999 (Corsaro \& Métrich, 2016)

$\times 2001$ (Métrich et al., 2004)

$+2002 / 3$ (Spilliaert et al., 2006a)

प2001 (Collins et al., 2009) 2002/3 South (MI) $\triangle 2006$ (MI) $\triangle 2008 / 9$ (MI) - 2013 (MI)

$\triangle 2002$ (Collins et al., 2009)

$\diamond 2004$ (Collins et al., 2009)

02006 (Collins et al., 2009)

-2007 (Collins et al., 2009)

$\square$ 2001(Schiavi et al., 2015)

$\triangle 2002$ (Schiavi et al., 2015)

○2006 (Schiavi et al., 2015)

$\checkmark 122$ BC (Moretti et al., 2018)

- 1997-99 (Moretti et al., 2018)

MELTS models

- high T-P, $\mathrm{NNO}+1$ and $\mathrm{NNO}+2$
- $\mathrm{NNO}+2,20 \mathrm{MPa}{ }^{\circ} \mathrm{C}^{-1}$
- $\mathrm{NNO}+2,5 \mathrm{MPa}^{\circ} \mathrm{C}^{-1}$
$-\mathrm{NNO}+2,3 \mathrm{MPa}^{\circ} \mathrm{C}^{-1}$
$-\mathrm{NNO}+1,20 \mathrm{MPa}^{\circ} \mathrm{C}^{-1}$
$--\mathrm{NNO}+1,5 \mathrm{MPa}{ }^{\circ} \mathrm{C}^{-1}$
$--\mathrm{NNO}+1,3 \mathrm{MPa}{ }^{\circ} \mathrm{C}^{-1}$




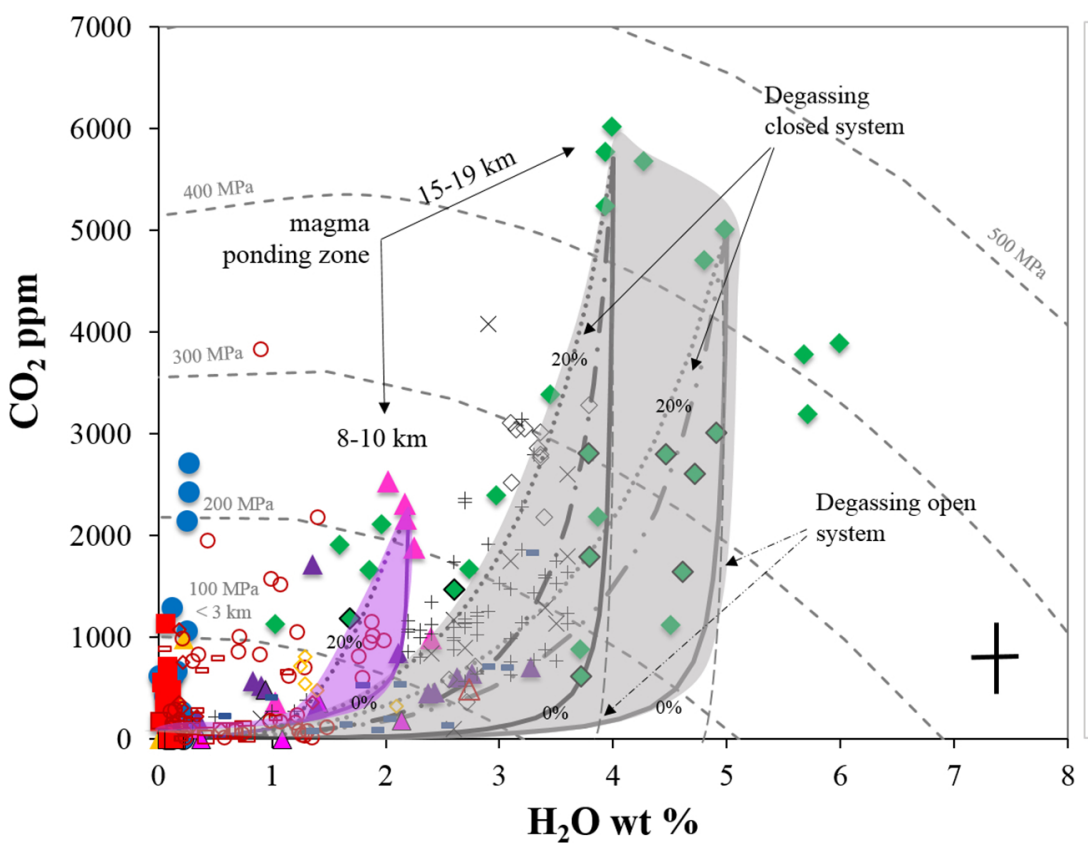

- Mt Spagnolo (SIMS)

- Mt Spagnolo (FTIR)

- FS (SIMS)

$\checkmark$ FS (FTIR)

$\triangle 2002 / 3$ South (SIMS)

$\triangle 2002 / 3$ South (FTIR)

\ 2006 (SIMS)

$\Delta 2006$ (FTIR)

$\triangle 2008 / 9$ (SIMS)

2013 (SIMS)

$\square 2013$ (FTIR)

$\diamond \mathrm{FS}$ (Kamenetsky et al.,2007)

$\times 2001$ (Métrich et al., 2004)

$+2002 / 3$ (Spilliaert et al., 2006)

$\square 2001$ (Collins et al., 2009)

$\triangle 2002$ (Collins et al., 2009)

$\checkmark 2004$ (Collins et al., 2009)

O 2006 (Collins et al., 2009)

-2007 (Collins et al., 2009)

$\checkmark 122$ BC (Moretti et al., 2018)

- 1997-99 (Moretti et al., 2018)

Figure 6 


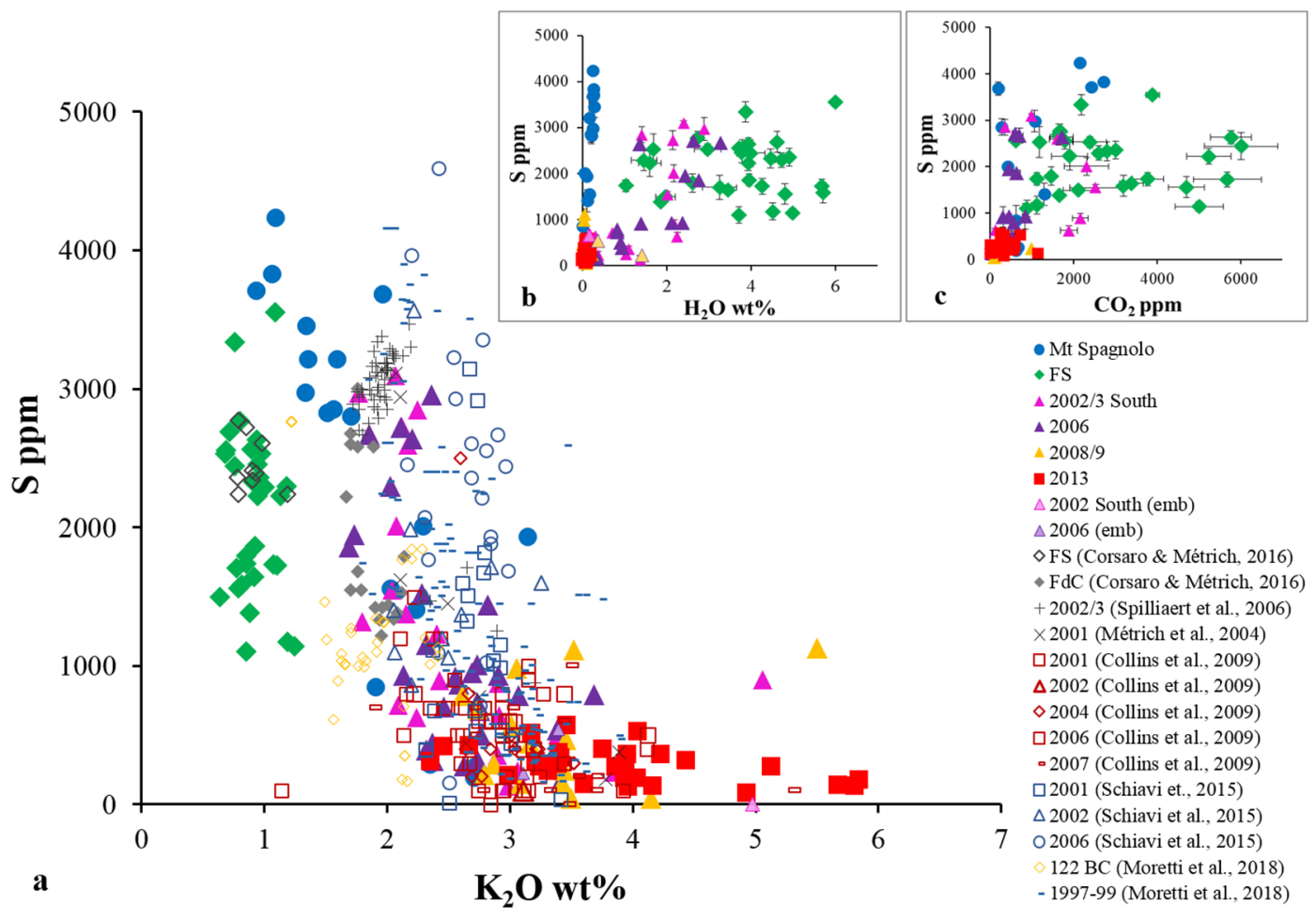

Figure 7 


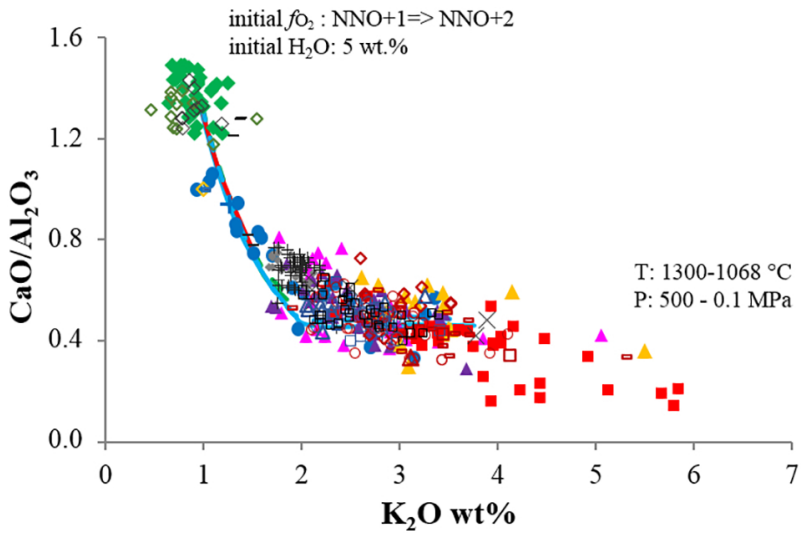

Figure 8 


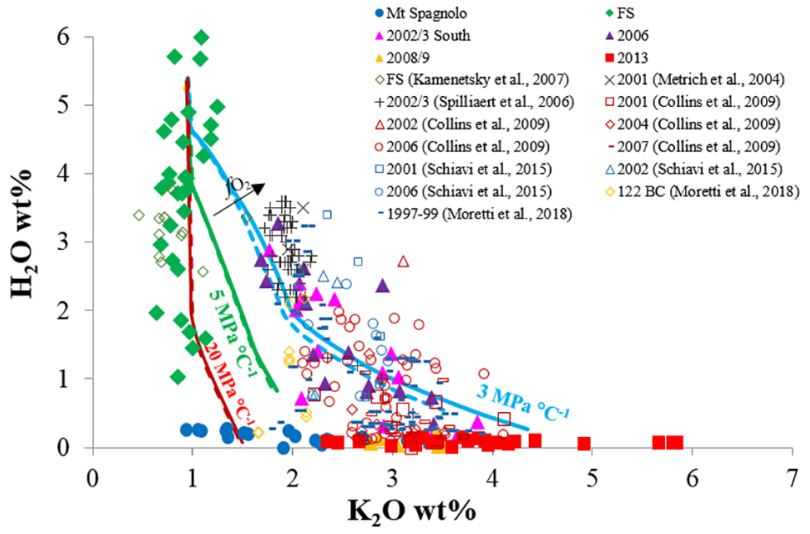

Figure 9 


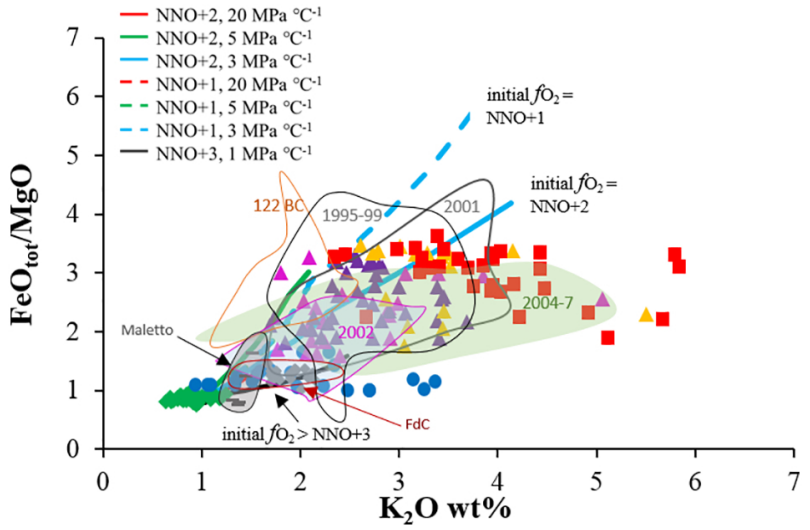

Figure 10 
$\mathrm{P}=\sim 150 \mathrm{MPa}$

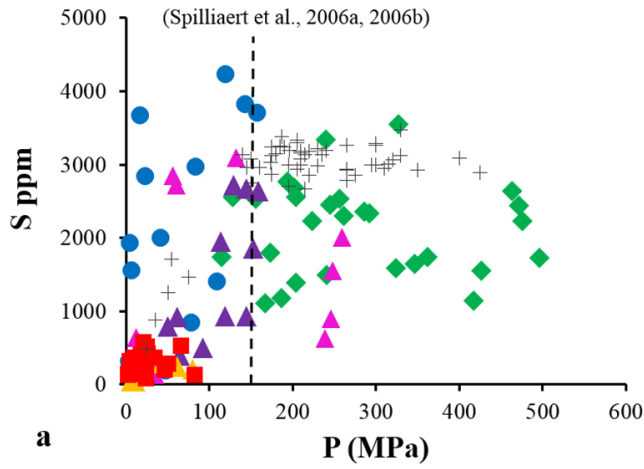

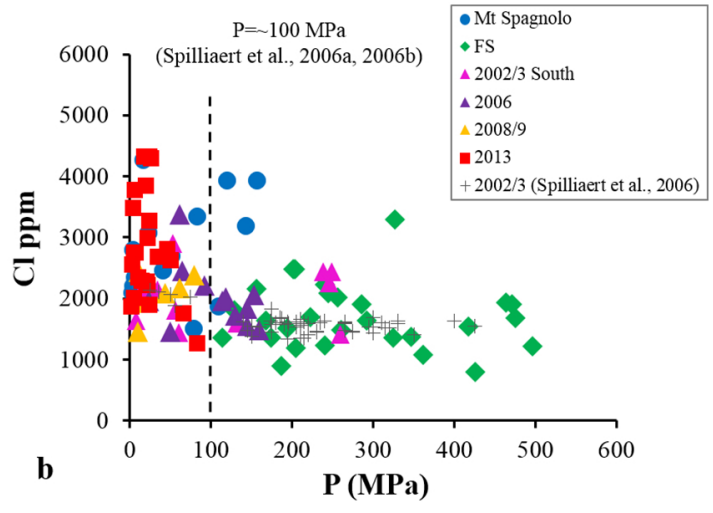

Figure 11 